\title{
The Damgaard flora: A new Middle Miocene flora from Denmark
}

\author{
ELSE MARIE FRIIS
}

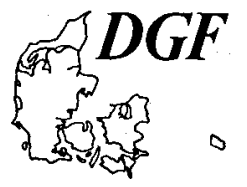

Friis, E. M.: The Damgaard flora: A new Middle Miocene flora from Denmark. Bull. geol. Soc. Denmark, vol. 27, pp. 117-142, Copenhagen, March 23rd, 1979.

https://doi.org/10.37570/bgsd-1978-27-12

\begin{abstract}
A new fossil flora consisting of fruits and seeds has been recovered from a sand bed of Middle Miocene age at the exposure "Damgaard $S \approx$ in the Søby-Fasterholt area, Denmark. 36 species have been recorded; the results of the floristic-climatic analyses indicate that the Damgaard flora is an arctotertiary flora that has grown under warm temperate to subtropical conditions. The most significant fossils in the Damgaard flora are the endocarps of Comptonia, assigned to a new species $C$. srodoniowae. Fruits and seeds of Arctostaphyloides menzelii, Empetrum sp., Proserpinaca brevicarpa, Rhus cf. toxicodendron and Visnea sp. have been recorded from Tertiary deposits of Denmark for the first time.
\end{abstract}

Else Marie Friis, Department of Geology, University of Aarhus, Universitetsparken, DK 8000 Arhus C. Denmark. July 4th, 1978.

During the summer of 1971 an exposure at the abandoned brown coal pit $\gg$ Damgaard $S_{«}$ in the Søby-Fasterholt area (figs 1,2 ) was studied as part of a sedimentological training project. The present author attended the project and collected samples for carpological studies. The investiga- tion was conducted by G. Larsen and H. Friis, Department of Geology, the University of Aarhus. A preliminary note on this work was given by Larsen \& Friis (1973). Examinations of trace fossils from the brown coal pit were carried out by Asgaard \& Bromley (1974). The locality

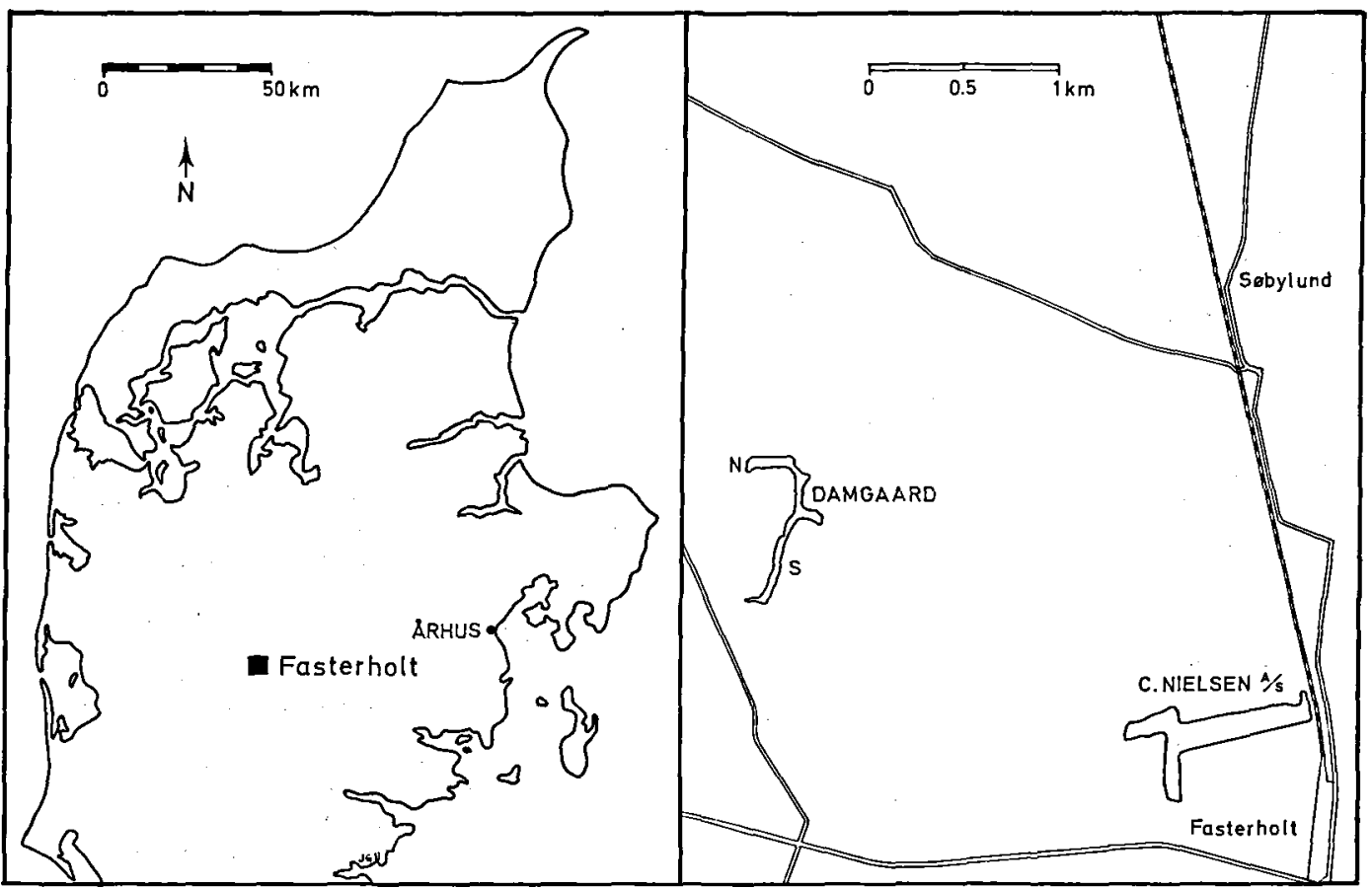

Fig. 1. Map showing main localities with plant macrofossils in the Søby-Fasterholt area. Damgaard N - Søby flora, Damgaard $S$-Damgaard flora, C. Nielsen A/S - Fasterholt flora. 
was also briefly mentioned by Koch et al. (1973) in the outline of the geology of the Søby-Fasterholt area.

\section{Locality and stratigraphy}

The brown coal pit "Damgaard $S$ « is situated in the Søby-Fasterholt area, Jylland, Denmark (fig. 1 ). The pit is abandoned and partly water-logged and the brown coal seams are totally submerged. The exposed section is composed of a 6-8 $\mathrm{m}$ thick series of Tertiary deposits overlain by $1.5-4 \mathrm{~m}$ of Quaternary deposits (figs 2, 3).

The Tertiary sequence consists of light cross-bedded sand discordantly overlain by up to $5 \mathrm{~m}$ of black, micaceous clay, which in the basal part is gravely. Larsen \& Friis (1973) referred the sand to the continental Odderup Formation (Middle Miocene) and the clay to the Marine Hodde Formation (uppermost Middle Miocene). According to S. Piasecki (personal communication 1978), who studied the dinoflagellate assemblages from the Hodde and Gram Formation, the entire Hodde Formation should be referred to the Upper Miocene. Ophiomorpha burrows which penetrate the sand from the basal gravel layer indicate that this facies was deposited in a littoral environment (Asgaard \& Bromley 1974). Where the clay sequence is thickest there is a gradual change from the dark Hodde clay into dark, glauconitic clay which belongs to the basal part of the marine Gram Formation (Upper Miocene). The above mentioned formations were defined by Rasmussen (1961).

Samples for carpological studies were collected from the light cross-bedded sand and the fossils were washed out in water in the laboratory. The fossil material consists predominantly of rounded pieces of wood, but in a few horizons fruits and seeds occur abundantly; these horizons numbered as: Dam 1, Dam 2, Dam 3, Dam 4, Dam 5 are indicated on figure 2 . The thick cross-bedded units constitute lateral successions (fig. 2); the sand sequence is thought to have been deposited during a rather short period, consequently the plant remains are treated collectively. There is no definite evidence for the depositional environment of the sand bed, and as the plant fossils are rather worn, probably caused by transportation, they cannot contribute to the understanding of the environment.

Silicified lower Palaeozoic fossils have also been found in the cross-bedded sand. They are similar to those described by Spjeldnæs (in Koch $\&$ Friedrich 1970), and they are probably derived from the central part of the Baltic area (Spjeldnæs 1975).

\section{The Damgaard flora}

The plant remains collected in the brown coal pit Damgaard $S$ are considered as one flora: the Damgaard flora. It comprises 36 species of fruits and seeds, and a few twigs (table 1). The preservation of the plant remains is variable, some fruits are badly worn while others have more fragile parts preserved, but they all give indication of a rather rough transportation. The preservation of the fruits and seeds does not allow detailed anatomical studies. The majority of species in the flora are represented by very few specimens; only a few species are well represented and allow more detailed descriptions and discussion.

The distribution of species throughout the profile is shown in table 1. Endocarps of Comptonia srodoniowae sp. nov. are the most common fos-

N
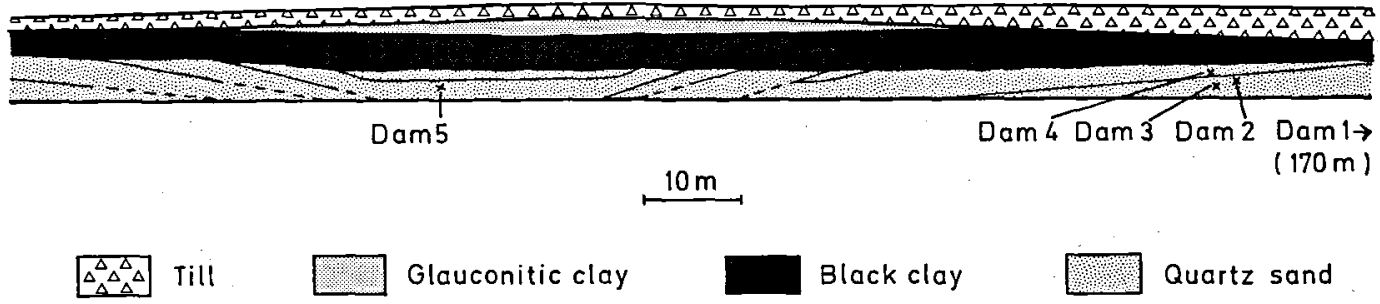

Quartz sand

Fig. 2. Sketch of the exposure at Damgaard S. The numbers indicate horizons where fruits and seeds occur abundantly. 


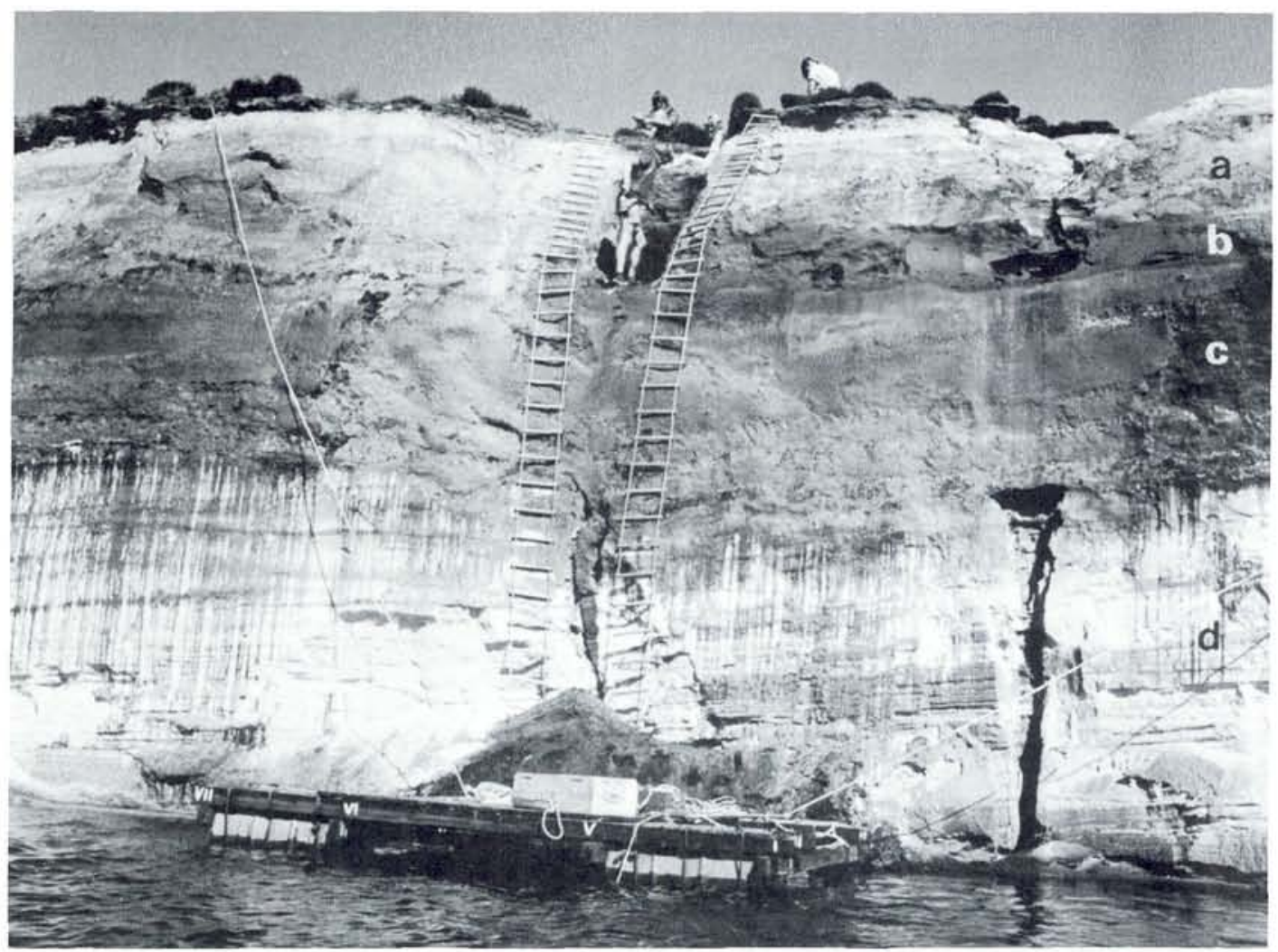

Fig. 3, View of the exposure at the brown coal pit Damgaard S. a $=$ Quaternary, $\mathrm{b}=$ glauconitic clay, $\mathrm{c}=$ dark clay, $\mathrm{d}=$ Quartz sand. (Photo K. Raunsgaard Pedersen).

sils in the Damgaard flora and they are found in all samples together with the endocarps of Myrica cf. ceriferiformis. Leaf whorls of Hellia salicornioides are found in four samples; all other species were found in less than four samples (table 1).

Climatic interpretation of the Damgaard flora is based on analyses of three different groupings of flora-elements: 1 . Arctotertiary - palaeotropical elements. 2. Herbaceous - arborescent elements (growth form). 3. Native - exotic elements (generic composition). Friis (1975), when applying these analyses to the Middle Miocene Fasterholt flora, gave a discussion of the methods.

The correlation between the content of palaeotropical species and the climate was discussed in detail by Mai $(1965,1967)$. The percentage of palaeotropical species is thought to increase with increasing temperature. Fossil floras dominated by the palaeotropical element are referred to as mastixioidean floras, and fossil floras dominated by the arctotertiary element are referred to as arctotertiary floras (Mai 1965). The Damgaard flora is an arctotertiary flora with $65 \%$ of the species referred to the arctotertiary element and $35 \%$ to the palaeotropical element. This percentage composition is regarded as an indication of warm temperate to subtropical conditions (Mai 1965).

The relationship between growth form and climate was studied by Bailey \& Sinnott (1916), and analyses of growth form have been applied to fossil floras by Reid \& Chandler (1933) and Szafer $(1946,1954,1961)$. Generally the percentage of arborescent species increases with increasing temperature when considering the dicotyledones. In the Damgaard flora the woody dicotyledonous species make up about $54 \%$ of all angiosperm species and $75 \%$ of all dicotyledonous species, which indicates tropical conditions. The high percentage of woody species may, in part at least, be a result of rough transportation with the loss of 
Table 1. Fossil species identified from the brown coal pit „Damgaard $\mathrm{S} \alpha$

Species Dam Dam Dam Dam Dam

\begin{tabular}{|c|c|c|c|c|c|}
\hline & 1 & 2 & 3 & 4 & 5 \\
\hline Pinus sp. & & & $\mathbf{x}$ & & \\
\hline Taxodium dubium & & & $\mathbf{x}$ & $\mathbf{x}$ & \\
\hline Hellia salicornioides & $\mathbf{x}$ & $\mathbf{x}$ & $\mathbf{x}$ & $\mathbf{x}$ & \\
\hline Brasenia cf. tenuicostata & $\mathbf{x}$ & & $\mathbf{x}$ & $\mathbf{x}$ & \\
\hline Comptonia srodoniowae & $\mathbf{x}$ & $\mathbf{x}$ & $\mathbf{x}$ & $\mathbf{x}$ & $\mathbf{x}$ \\
\hline Myrica cf. ceriferiformis & $\mathbf{x}$ & $x$ & $\mathrm{x}$ & $\mathbf{x}$ & $\mathbf{x}$ \\
\hline Myrica cf. minima & $\mathbf{x}$ & $\mathbf{x}$ & $\mathbf{x}$ & & \\
\hline Myrica ef. suppanii & $\mathbf{x}$ & & $\mathbf{x}$ & & \\
\hline Pterocarya sp. & $\mathbf{x}$ & & & & \\
\hline Eurya stigmosa & $\mathbf{x}$ & $\mathbf{x}$ & & & \\
\hline Visnea sp. & $\mathbf{x}$ & & & & \\
\hline Arctostaphyloides menzelii & $\mathbf{x}$ & & $\mathbf{x}$ & & \\
\hline Epacridicarpum sp. & & & $\mathbf{x}$ & & \\
\hline Ericaceae gen.? & & & $\mathbf{x}$ & & \\
\hline Empetrum sp. & & & $\mathbf{x}$ & & \\
\hline Halesia crassa & $\mathbf{x}$ & & & & \\
\hline Intratriporopollenites & & & & & \\
\hline instructus & & & $\mathbf{x}$ & & \\
\hline Aldrovanda praevesiculosa & & & & & $\mathbf{x}$ \\
\hline Cecodon gibbosus & & & $\mathbf{x}$ & & \\
\hline Proserpinaca brevicarpa & & & $\mathbf{x}$ & & \\
\hline Rhus cf. toxicodendron & & & $\mathbf{x}$ & & \\
\hline Palirus sp. & & & $\mathbf{x}$ & & \\
\hline Vitis cf. silvestris & & & $\mathbf{x}$ & $\mathbf{x}$ & \\
\hline Alismataceae gen.? & & & $\mathbf{x}$ & & $\mathbf{x}$ \\
\hline Potamogeton heinkei & & & & $\mathbf{x}$ & \\
\hline Cladium reidiorum & & & & $\mathbf{x}$ & \\
\hline Cladium cf. crassum & & $\mathbf{x}$ & & $\mathbf{x}$ & \\
\hline Scirpus ragozinii & & $\mathbf{x}$ & $\mathbf{x}$ & & $\mathbf{x}$ \\
\hline Scirpus ? sp. & & & $\mathbf{x}$ & & \\
\hline Cyperaceae gen.? sp. 1 & & & $\mathbf{x}$ & & \\
\hline Cyperaceae gent? sp. 2 & & & $\mathbf{x}$ & & \\
\hline Sparganium camenzianum & & $\mathbf{x}$ & $\mathbf{x}$ & & \\
\hline Carpolithus sp. 1 & & & & $\mathbf{x}$ & \\
\hline Carpolithus sp. 2 & & & $\mathbf{x}$ & & \\
\hline Carpolithus sp. 3 & $\mathbf{x}$ & & & & \\
\hline Carpolithus sp. 4 & & & $\mathbf{x}$ & & \\
\hline
\end{tabular}

the more delicate seeds of the herbaceous plants. It should be noted that the statistical basis is rather unreliable as only 16 dicotyledonous species have been considered.

The relationship between the native and exotic elements in a fossil flora and the palaeoclimate was discussed by Wolfe \& Barghoorn (1960). The percentage of exotic elements are thought to increase with increasing temperature. In the Damgaard flora $53 \%$ of the species may be included in the native element and $47 \%$ in the exotic element, which also indicates a warm climate. The native element here includes fossil species referred to extant genera now living in parts of the Middle European flora region (cf. Friis 1975). The exotic element includes fossil species referred to genera, which are not represented in this area today.

The majority of species of the Damgaard flora have been compared to extant species, which are distributed within the warm temperate and subtropical regions of the world, and although the statistical foundation, on which the climatic analyses are based is slender, it may be concluded that the climatic conditions which prevailed in the Søby-Fasterholt area when the Damgaard flora existed were warm temperate to subtropical.

Two Middle Miocene floras have previously been described from the Søby-Fasterholt area: The Fasterholt flora and the Søby flora (fig. 1). The stratigraphic relationship between the three floras is shown in figure 4 .

The Søby flora was discovered in the abandoned brown coal pit "Damgaard N (fig. 1) by E. Fjeldsø Christensen, who recognised 16 species of leaves and fruits preserved in a brownish clay; parts of the taxonomic study of the Søby flora are already published (Christensen 1975, 1976). Samples of the plant bearing clay were separated by wet sieving for carpological studies and about 15 species of fruits and seeds were found. Geographically and stratigraphically the Søby flora is very close to the Damgaard flora (figs 1, 4). However, the two floras differ in many respects, which may be attributed to the difference in depositional environments and in the nature of the fossils. The Søby flora, which is deposited in clay, is thought to represent the vegetation of a restricted area, and the plant material has not been subjected to long transportation (leaves usually well preserved). The Damgaard flora, however, is deposited in sand and is thought to contain representatives of various local and regional vegetation; the plant material has been subjected to rather rough transportation (fruits and seeds usually worn). In spite of the difference in the depositional environment and the nature of the fossils, the Søby flora and the Damgaard flora also show some similarity. The most common fossils in the Damgaard flora are the endocarps of Comptonia srodoniowae sp. nov. Comptonia is also very common in the Søby flora, where it is represented by leaves of $C$. $a c u-$ tiloba (Christensen 1975) and endocarps of $C$. srodoniowae sp. nov. The endocarps of Comptonia from the two localities are very similar in size and shape. Conifers referred to Pinus, Taxodium 


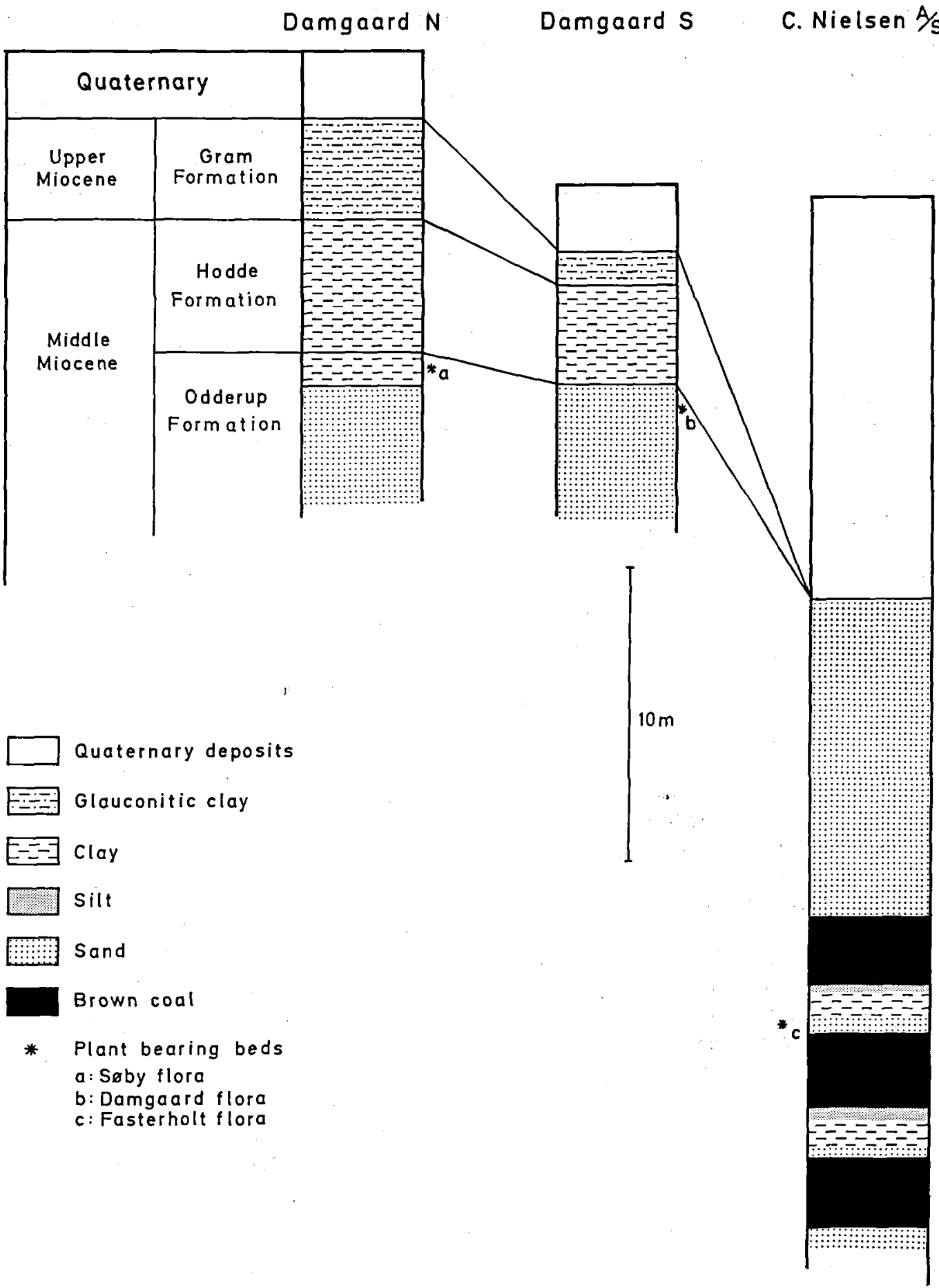

Fig. 4. Stratigraphical correlation of exposures with plant macrofossils in the Soby-Fasterholt area (compiled from Larsen \& Friis 1973, Christensen 1975). 
and Hellia salicornioides are also found in both floras, together with fruits and seeds of Myrica, Halesia, Proserpinaca, Alismataceae, Sparganium, Potamogeton and Scirpus. In the Damgaard flora the palaeotropical element constitutes $35 \%$ of the species, whereas only one species from the Søby flora can be referred to this element.

The Fasterholt flora was discovered in the brown coal pit »C. Nielsen $A / S$ « near Fasterholt (fig. 1) (Koch \& Friedrich 1970, Koch et al. 1973). The flora is very rich and comprises more than 150 species of fruits, seeds, megaspores and leafy shoots. The preservation of the plant material is usually excellent and allows detailed morphological and anatomical studies, which was demonstrated by Koch \& Friedrich (1971) and Friis (1977a, 1977b). The Fasterholt flora is accumulated in a fine grained sand bed intercalated between the two uppermost brown coal layers; it is thought to represent various plant communities from a rather local flora, and generally the fossils show no evidence of long transportation. The Damgaard flora has many species in common with the Fasterholt flora, but some species have not been recorded in the Fasterholt flora: Arctostaphyloides menzelii, Empetrum sp., Halesia crassa, Intratriporopollenites instructus, Proserpinaca brevicarpa, Rhus cf. toxicodendron and Visnea sp. Intratriporopollenites instructus is represented in the Damgaard flora by pollen-sacs with pollen. Similar dispersed pollen grains were also found in the lignite from the brown coal pit $» C$. Nielsen $A / S$ « (Friis \& Pedersen in prep.). Floristic-climatic analyses based on the small sized plant remains show that the Fasterholt flora is an arctotertiary flora in which about $60 \%$ of the species may be referred to the arctotertiary element (Friis 1975). The climatic conditions of the Damgaard flora and the Fasterholt flora are thought to have been rather similar.

\section{Systematic description}

Division: Gymnospermae

Class: Coniferopsida

Family: Abietaceae

Genus: Pinus Linné
Material: One seed

Occurrence: Dam 3.

Remarks. Macrofossils ascribed to Pinus occur rather seldom in the Tertiary deposits of Denmark. One dwarf shoot of Pinus palaeostrobus was described from the fossiliferous clay at Fasterholt by Mathiesen (1970) and few seeds of Pinus were also recorded from the Fasterholt flora (Friis 1975). Cones ascribed to $P$. thomasianum were found in the Søby flora by Christensen (1975) and at Sønderskov, Jylland, by Hartz (1909).

The extant species of Pinus are very difficult to distinguish on seed-characters. No fossil species of Pinus is based only on seeds and the present specimen is referred to Pinus sp.

Family: Taxodiaceae

Genus: Taxodium Richard

\section{Taxodium dubium (Sternberg) Heer}

1823. Phyllites dubius Sternberg - Sternberg p. 37, pl. 36:3.

1853. Taxodium dubium Heer - Heer p. 49, pl. 17:5-15.

Material: 6 seeds and about 60 fragments of seeds, 1 fragment of cone-scale.

Occurrence: Dam 3, Dam 4.

Remarks. Plant remains ascribed to Taxodium are very common in the plant-bearing Miocene deposits of Jylland. Mathiesen (1970) described well-preserved seeds, foliage twigs and cone scales of T. dubium from the lignitic clay at Moselund. From the Søby flora seeds of $T$. dubium were likewise described together with shoots and cones (Christensen 1975). Twigs, cones and seeds of Taxodium are among the most numerous fossils in the Fasterholt flora (Koch et al. 1973). The seeds from the Damgaard flora are in complete agreement with other seeds of $T$. dubium previously described from the Tertiary of Denmark.

Family: Cupressaceae

Genus: Hellia Unger

Hellia salicornioides Unger

Figs 5B, C.

\section{Pinus sp.}

Fig. 5A

1840. Hellia salicornioides - Unger p. 375. 


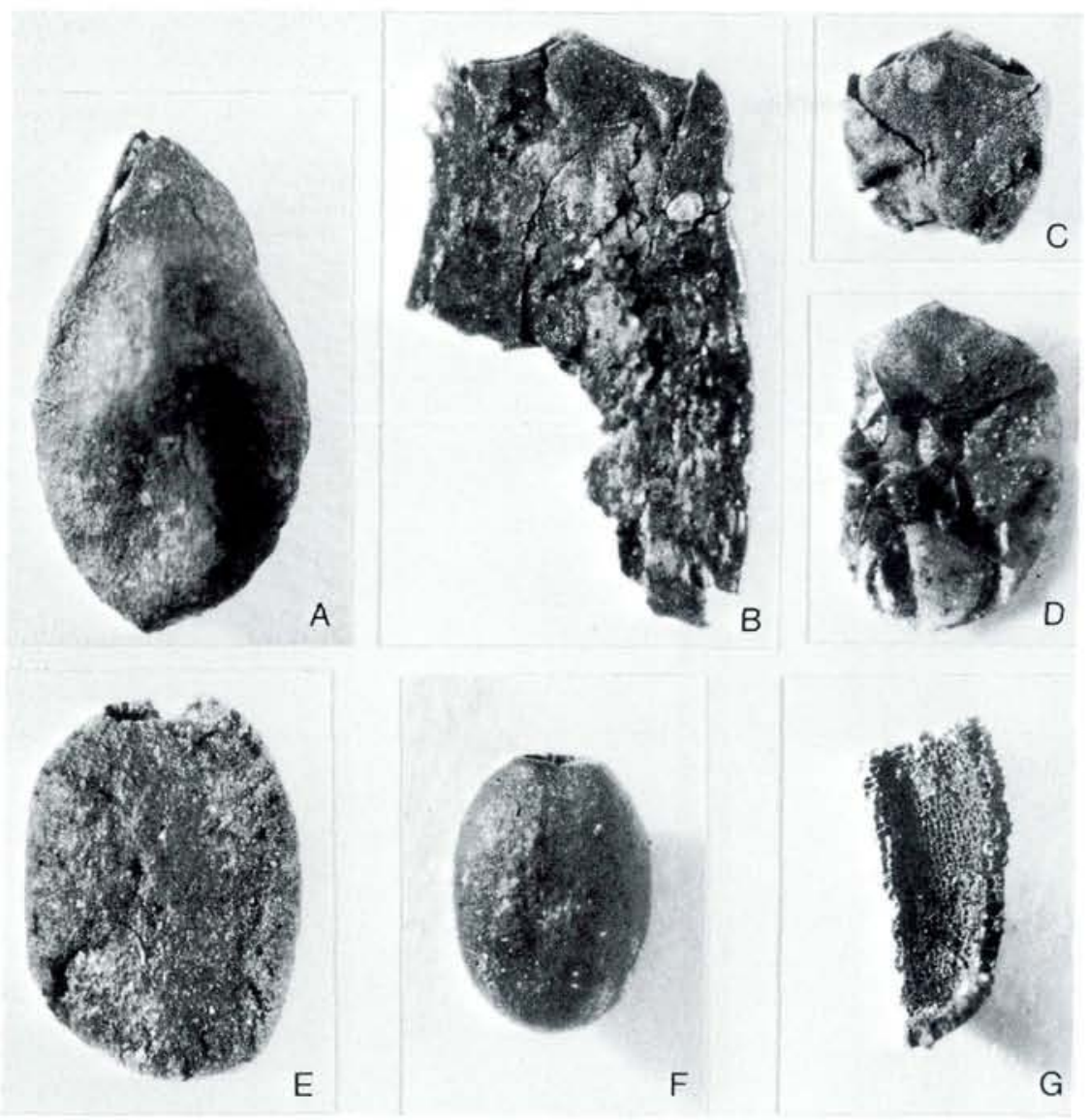

Fig. 5. A, Pinus sp., seed. B-C, Hellia salicornioides leaf whorls. $D-G$, Brasenia $c f$. tenuicostata. $D$, inner integument.

1847. Thuytes salicornioides Ung. - Unger p. 11, pl. 2: $1-4,7$.

1977a. Hellia salicornioides Unger - Friis p. 104, figs 1-13.

Material: 8 fragments of leaf whorls.

Occurrence: Dam 1, Dam 2, Dam 3, Dam 4.

Remarks. The present material is similar in both morphological features and epidermal structure to those described from the fossil flora of Fasterholt (Friis 1977a). Fragments of H. salicornioides were also found in the transitional bed of alternating sand and clay below the plant-bearing bed at the locality Damgaard N. Twigs of $H$. salicornioides are very common in younger Tertiary plant-bearing beds of Europe; it belongs to an extint genus Hellia, which is closely related to the extant Tetraclinis (Friis 1977a).
$E-F$, seeds, $G$, inner surface of outer integument showing digitate sclereids. $\times 15$.

Division: Angiospermae

Class: Dicotyledones

Family: Cabombaceae

Genus: Brasenia Schreber

Brasenia cf. tenuicostata Nikitin

Figs 5D-G.

Material: 10 seeds, 6 fragments of seeds, 6 inner integuments.

Occurrence: Dam 1, Dam 3, Dam 4.

Description. Seeds anatropous, elongated elliptic, $1.5-2.8 \mathrm{~mm}$ long, average $=2.4 \mathrm{~mm}, 1.1-2.0$ $\mathrm{mm}$ in diameter, average $=1.6 \mathrm{~mm}, 10$ specimens measured. Seed wall consists of two distinct layers. Outer integument $0.15-0.19 \mathrm{~mm}$ thick, built of palisade-shaped sclereids with strongly pitted anticlinal walls. The inner integument is 
very thin, membraneous and yellowish, with a conspicuous, circular and thickened chalaza at the base and a pointed micropylar part at the apex (fig. 5D). The outer surface of the seed is granular, black and with inconspicuous pattern of the strongly digitate sclereids. Hilum and micropyle are placed close together on a conical structure at the apex of the seed.

Remarks. Fossil seeds of Nymphaeales have been classified primarily on the basis of position of hilum and micropyle and the wall structure (Dorofeev in Dorofeev et al. 1974). The seeds from Damgaard are similar to those from Fasterholt assigned to Brasenia tenuicostata (Friis 1975). They correspond exactly with modern Brasenia in the features of the hilum and microplyle as well as wall structure. About 20 fossil species of Brasenia have previously been described from the Tertiary of Europe and Asia. In regard to external features the Danish seeds agree with those of Brasenia tenuicostata described by Nikitin (1965) from the Tertiary of western Siberia, but they differ in having a slightly thicker seed wall. They also resemble the seeds of $B$. teumeri Kirchheimer (1935), but they differ from this species in having a much thinner seed wall. According to $M$. Collinson (personal communication 1978) B. teumeri differs from modern Brasenia in the position of hilum and micropyle. Seeds of Nymphaeales from the Eocene of Geiseltal, GDR, described as $B$. cf. teumeri by Mai (1976) differ from $B$. teumeri in having a thinner seed wall; they will be described as a new species by Mai in a coming paper. The Danish specimens seems to be related to the Geiseltal material both in regard to internal and external features.

Brasenia is a monotypic genus of aquatic plants which is widely distributed in tropical and subtropical regions of the world. According to Koch (1931), who studied a large amout of extant $B$. purpurea (= B. schreberi) seeds, the surface ornamentation varies considerably from smooth to completely spiny specimens; the variation found in the extant species is possibly the result of climatic conditions as spiny specimens were found in tropical regions of Africa and India, whereas smooth or slightly spiny specimens were found in the extra-tropical regions of North America, Japan and Australia (Koch 1931).

Family: Myricaceae

Genus: Comptonia Banks

Comptonia srodoniowae sp. nov.

Figs 6A-L.

1974. Comptonia longistyla (Nikitin) Dorofeev Friis p. 267, figs 1g-i.

1975. Comptonia longistyla (Nikitin) Dorofeev Friis p. 180.

Diagnosis. Endocarps elongated ovoid, fusiform or guttiform, apex acuminating into style base. Endocarp one-loculed, two-valved with dehiscence along a marginal suture. External surface with one to nine conspicuous, usually high longitudinal ribs, extending from the base to the middle of the endocarp. Locule guttiform, tapering into a long apical stylar canal. Surface of locule smooth with small equiaxial cells. Endocarp wall consists of small, isodiametric stone cells; thickness of wall at dehiscence plane about $0.3 \mathrm{~mm}$.

Length of endocarp: $2.0-4.4 \mathrm{~mm}$

Breadth of endocarp: $0.8-2.1 \mathrm{~mm}$

Table 2. Measurements of Comptonia srodoniowae sp. nov. from Denmark: Length of endocarps.

\begin{tabular}{cccccccc}
\hline & $\begin{array}{c}\text { Length } \\
(\mathrm{mm}):\end{array}$ & $2,01-2,4$ & $2,41-2,8$ & $2,81-3,2$ & $3,21-3,6$ & $3,61-4,0$ & $4,01-4,4$ \\
\hline \multirow{2}{*}{$\begin{array}{c}\text { number of } \\
\text { specimens }\end{array}$} & 1 & 4 & 9 & 17 & 9 & 4 \\
\hline & $\%$ & 2,3 & 9,1 & 20,4 & 38,7 & 20,4 & 9,1 \\
\hline \multirow{2}{*}{ Fasterholt } & $\begin{array}{l}\text { number of } \\
\text { specimens }\end{array}$ & 4 & 11 & 9 & 5 & 3 & 1 \\
\hline
\end{tabular}




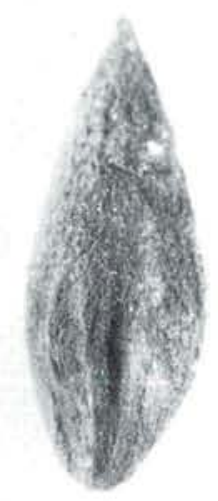

A

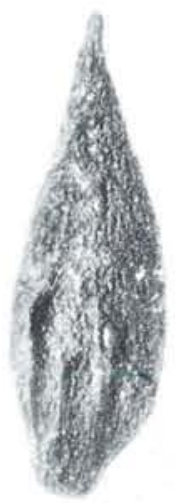

B
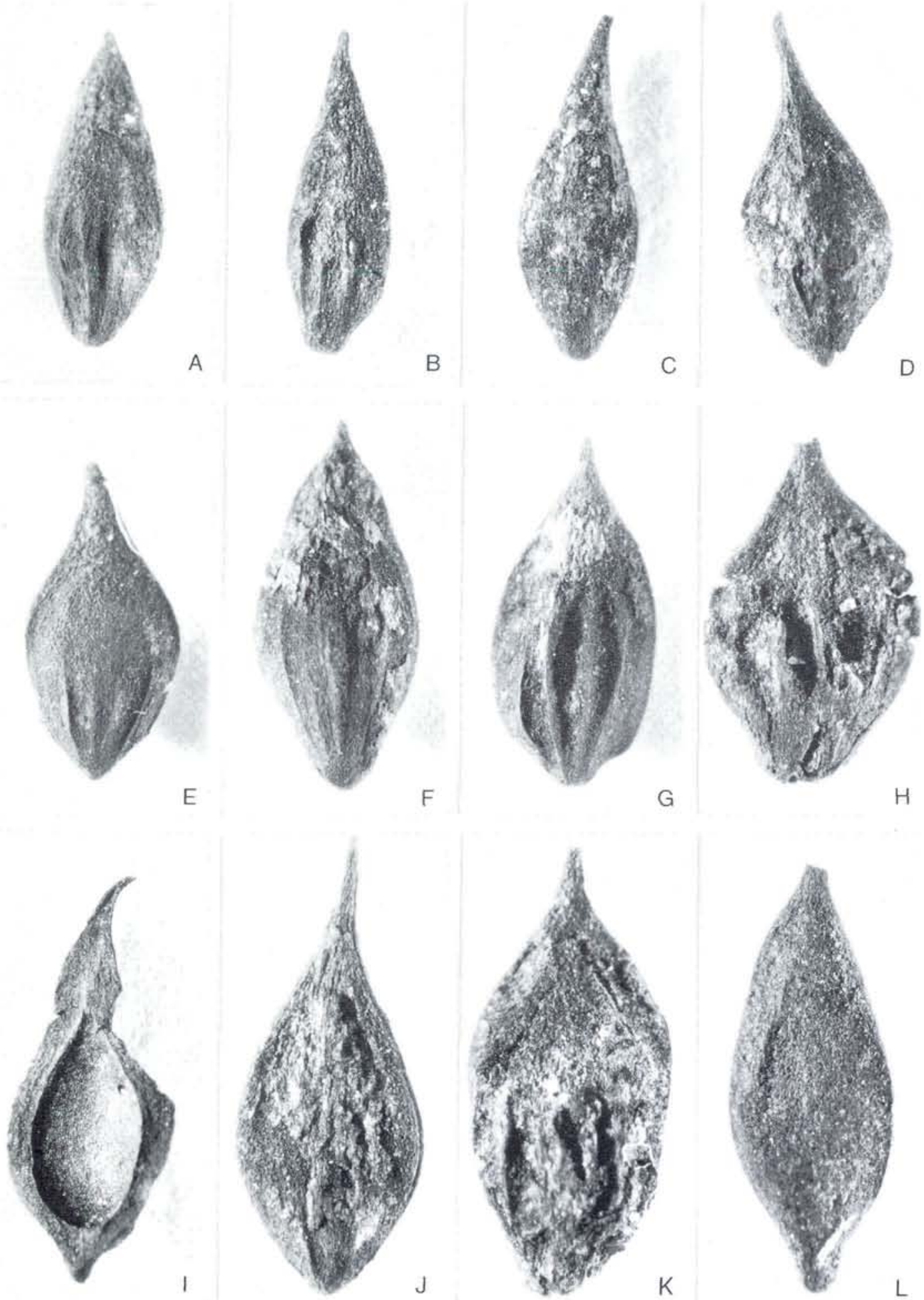

Fig. 6. Comptonia srodoniowae sp. nov., endocarps, G, Holotype. $\times 15$. 
Holotype: Fig. 6G.

Type locality: Brown coal pit »Damgaard $S \ll$, Fasterholt, Denmark.

Type stratum: Odderup Formation. Middle Miocene.

Derivation of name: Dr. M. Łańcucka-Środoniowa, Polish palaeobotanist.

Material: 44 endocarps and 56 fragments of endocarps.

Occurence: Dam 1, Dam 2, Dam 3, Dam 4, Dam 5.

Description. The endocarps are very variable in size and shape, bisymmetric and one-loculed. The dehiscence is along a marginal suture in the plane of symmetry and the endocarps split into two equal valves (figs $6 \mathrm{I}-\mathrm{J}$ ). They are elongated ovoid, guttiform or fusiform in outline, usually somewhat flattened at the margins of the valves and at the apical part of the endocarps. The apex

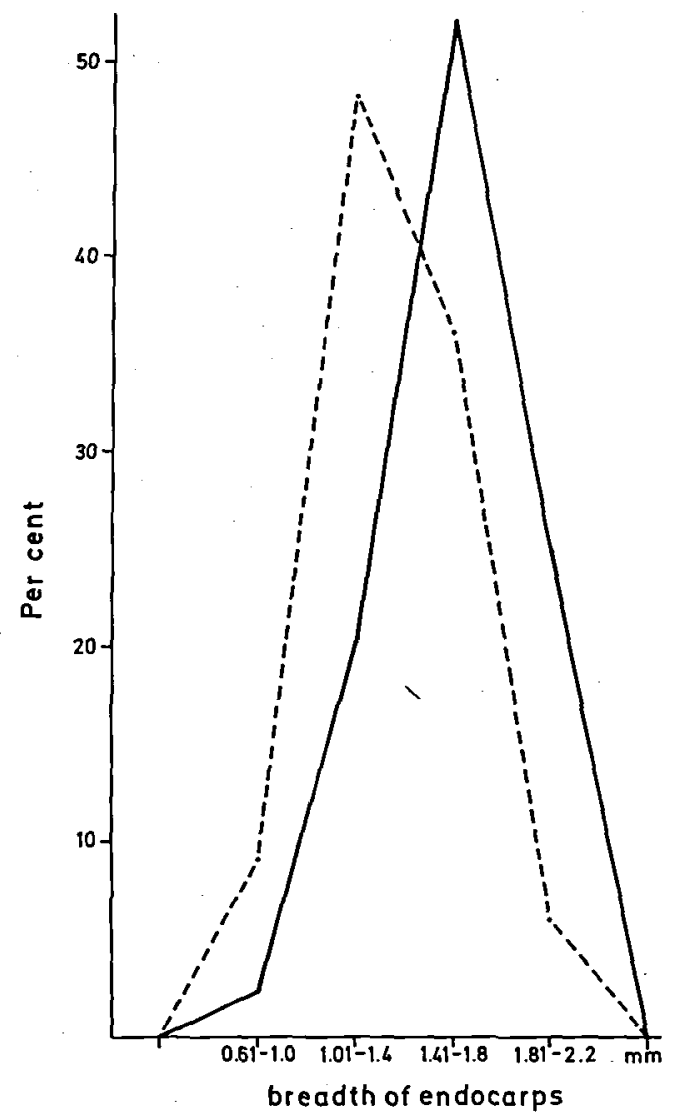

Fig. 7. Curves showing variability of length and breadth of
Comptonia srodoniowae sp. nov. from the Damgaard and Fasterholt floras.
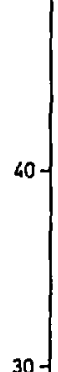

20 is acuminating, often into a long mucronate style base, which is sometimes slightly curved (figs 6C-D). The endocarps are somewhat pointed at the base. The length of the endocarps: $2.0-4.4$ $\mathrm{mm}$, average $=3.7 \mathrm{~mm}$ (fig. 7 , table 2). Breadth: $0.8-2.1 \mathrm{~mm}$, average $=1.6 \mathrm{~mm}$ (fig. 7 , table 3 ).

The endocarp wall is at the dehiscence plane about $0.3 \mathrm{~mm}$ thick. The cell structure is inconspicuous. The locule is guttiform and tapers into a long apical stylar canal. At the base there is a straight vascular canal, about $0.4 \mathrm{~mm}$ long. The equiaxial cells, about $0.02 \mathrm{~mm}$ in diameter.

The external surface shows one to nine conspicuous longitudinal ribs or crests extending from the base to the middle of the endocarp or very seldom to the apex; the shape and length of the ribs are very variable (figs $6 \mathrm{~A}-\mathrm{L}$ ), but they are usually acute-edged and sometimes rather high near the middle of the endocarp (fig. $6 \mathrm{G}$ ). In a surface of the locule is smooth and shows small 
Table 3. Measurements of Comptonia srodoniowae sp. nov. from Denmark: Breadth of endocarps.

\begin{tabular}{|c|c|c|c|c|c|}
\hline & $\begin{array}{l}\text { Breadth } \\
\text { (mm): }\end{array}$ & $0,61-1,0$ & $1,01-1,4$ & $1,41-1,8$ & $1,81-2,2$ \\
\hline \multirow{2}{*}{ Damgaard } & $\begin{array}{l}\text { number of } \\
\text { specimens }\end{array}$ & 1 & 9 & 23 & 11 \\
\hline & & & 20,4 & 52,3 & 25 . \\
\hline \multirow{3}{*}{ Fasterhol } & $\begin{array}{l}\text { number of } \\
\text { specimens }\end{array}$ & 3 & 16 & 12 & 2 \\
\hline & & & & & \\
\hline & $\%$ & 9,1 & 48,5 & 36,4 & 6,0 \\
\hline
\end{tabular}

few specimens remains of a thin exocarp are preserved.

Remarks. The above described endocarps are referred to the genus Comptonia. The genus includes only one extant species, $C$. perigrina, that is restricted to the eastern North America (Small 1972). In the Tertiary, however, the genus was widely distributed in the fossil floras of Europe, Asia and North America. The fossil record of Comptonia extends from the Upper Cretaceous to Miocene in Asia and from Eocene to Miocene in Europe; in North America Comptonia is known from the Upper Cretaceous to the present (Budancev \& Gladkova 1963). The genus was very common in the Lower Tertiary floras of North America, but during the Neogene the occurrence decreased in North America, and Comptonia was much more aboundant in Asia than in America (Chaney 1967). Gladkova (1965) distinguished 11 species of Comptonia from Western Siberia based on palynological studies. The characteristic, deeply lobed leaves of Comptonia are also widespread in the fossil floras of Asia and Europe (Budancev \& Gladkova 1963, Zhilin 1974, Rüffle 1976). Based on studies of endocarps 9 fossil species of Comptonia were established from Tertiary deposits of the USSR (table 5).

Endocarps of Comptonia are also known from the Fasterholt flora (Friis 1974). They are very closely related to the endocarps from the Damgaard flora as regards their shape and surface ornamentation, but the endocarps from Fasterholt are generally smaller than those from Damgaard (table 3,4 ). To facilitate the comparison of the material from the two localities, the percentage distributions of the measurements were calculat- ed and expressed in figure 7. They are regarded as belnnging to the same species and the vari in size iray be attributed to difference in eivironmental conditions. The endocarps from F. terholt were previously assigned to C. longistyla, but with this rich find of Comptonia-en. . varps in the Damgaard flora, the Danish mater ial shows a greater variation in size and shape than is known for C. longistyla (table 5); they also differ from $C$. longistyla by having generally shorter and higher ribs; a new species, $C$. srodoniowae is therefore established for the Danish material. Few specimens from the Damgaard flora are also related to C. tymensis (e.g. figs $6 \mathrm{H}, \mathrm{K}$ ), but there is a gradual change from one type to another.

Leaves of Comptonia acutiloba were recorded from the nearby Søby flora (Christensen 1975) as well as a few fruits clearly assignably to $C$. srodoniowae. It is very likely that the endocarps of $C$. srodoniowae and the leaves of $C$. acutiloba come from the same plant, but they have not been found in organic connection. According to Rüffle (1976) C. acutiloba is conspecific with $C$. diformis.

Genus: Myrica Linné

Myrica cf. ceriferiformis Kownas

Fig. 8A.

Material: 15 endocarps, 27 fragments of endocarps.

Occurrence: Dam 1, Dam 2, Dam 3, Dam 4, Dam 5.

Description. Endocarps one-loculed, ovate and bisymmetric, at dehiscence splitting into two valves. Length $2.1-2.7 \mathrm{~mm}$; breadth $1.5-2.2 \mathrm{~mm}$. Locule ovate, apically tapering into a short stylar 
Table 4. Fruit characters of fossil and extant Comptonia

\begin{tabular}{|c|c|c|c|c|}
\hline Species & Author & Length mm & Breadth mm & $\begin{array}{l}\text { Shape of endocarp } \\
\text { and ribs }\end{array}$ \\
\hline C.aldanensis & Dorofeev 1966 & $2.8-4.6$ & $1.3-2.6$ & $\begin{array}{l}\text { elliptic } \\
\text { ribs many, conspicuous }\end{array}$ \\
\hline C.baranovae & V. Nikitin 1976 & $1.9-2.5$ & $1.1-1.4$ & $\begin{array}{l}\text { elliptic } \\
\text { ribs conspicuous }\end{array}$ \\
\hline C.costata & Dorofeev 1966 & $4.0-5.0$ & $2.2-3.0$ & $\begin{array}{l}\text { ovate } \\
\text { ribs many, conspicuous }\end{array}$ \\
\hline C.crassa & Dorofeev 1966 & $3.9-4.9$ & $2.6-3.2$ & $\begin{array}{l}\text { elliptic } \\
\text { no ribs }\end{array}$ \\
\hline C.debilis & V. Nikitin 1976 & $1.5-2.0$ & $0.8-1.0$ & $\begin{array}{l}\text { fusiform or guttiform } \\
\text { ribs inconspicuous }\end{array}$ \\
\hline C.gorbunovii & Dorofeev 1966 & $3.2-5.2$ & $1.9-4.6$ & $\begin{array}{l}\text { ovate } \\
\text { ribs many, conspicuous }\end{array}$ \\
\hline C.longistyla & $\begin{array}{l}\text { P. A. Nikitin } 1965 \\
\text { Dorofeev } 1966\end{array}$ & $2.0-3.2$ & $1.6-2.7$ & $\begin{array}{l}\text { guttiform to fusiform } \\
\text { ribs conspicuous,not high }\end{array}$ \\
\hline C.tiulinae & Dorofeev 1966 & $1.9-4.2$ & $1.0-2.5$ & $\begin{array}{l}\text { elliptic } \\
\text { ribs thin }\end{array}$ \\
\hline C.tymensis & Dorofeev 1966 & $3.3-5.0$ & 1.82 .3 & $\begin{array}{l}\text { broadly ovate } \\
\text { ribs conspicous }\end{array}$ \\
\hline C.srodoniowae & Friis sp. nov. & $2.0-4.4$ & $0.8-2.1$ & $\begin{array}{l}\text { guttiform to fusiform } \\
\text { ribs consipcuous, often high }\end{array}$ \\
\hline C.perigrina & $\begin{array}{l}\text { Linné } \\
\text { Coulter }\end{array}$ & $3.1-4.8$ & $2.1-3.0$ & $\begin{array}{l}\text { ovate } \\
\text { ribs inconspicuous }\end{array}$ \\
\hline
\end{tabular}

canal, and with a slightly projecting placenta at the base. Surface of locule with small equiaxial cells. Endocarp wall about $0.2 \mathrm{~mm}$ thick. In some specimens parts of exocarp are preserved (fig. 8A). It consists of closely spaced, nearly isodiametric warts, about $0.2 \mathrm{~mm}$ in diameter, that form a honey-combed shaped pattern on the surface.

Remarks. The endocarps from the Damgaard flora closely resemble those of $M$. ceriferiformis described from the Tertiary of Poland by Kownas (1955), but they are slightly smaller. They were compared to the extant $M$. cerifera and $M$. caroliniana from eastern North America. Endocarps assigned to $M$. cf. ceriferiformis are among the most numerous fossils in the Fasterholt flora.

\section{Myrica cf. minima Negru}

Fig. 8B.

Material: 3 endocarps, 6 fragments of endocarps. Occurrence: Dam 1, Dam 2, Dam 3.

Description. Endocarps subglobular, slightly pointed at the apex. Length $1.3-1.6 \mathrm{~mm}$; breadth 1.3-1.7 mm. Endocarp wall about $0.2 \mathrm{~mm}$ thick.

Remarks. The above described endocarps are closely related to those of $M$. cf. ceriferiformis, but they differ in the more globular shape and the smaller size. In regard to shape and size they agree with those of $M$. minima described from the Miocene of Moldavia, USSR, by Negru (Dorofeev \& Negru 1970), but there is no information on the shape of the locule, for which reason the Danish material could not be referred to this species with certainty.

Myrica cf. suppanii Kirchheimer

Figs 8C-D.

Material: 5 endocarps.

Occurrence: Dam 1, Dam 3.

Description. Endocarp elliptical to subcircular, 2.6-3.2 $\mathrm{mm}$ long and $2.0-2.5 \mathrm{~mm}$ broad. Endocarp wall $0.2-0.45 \mathrm{~mm}$ thick at the plane of dehiscence; in the median region it is up to $0.8 \mathrm{~mm}$ thick.

Remarks. The endocarps are closely related to those of $M$. suppanii described from Wiesa by Kirchheimer (1938a) and from Ragewitz and Merka (1939), but they are generally slightly smaller and more ovate in shape than other endocarps ascribed to $M$. suppanii. They differ from the endocarps of $M$. cf. ceriferiformis and $M$. cf. mini$m a$ in their larger size and thicker endocarp wall. 


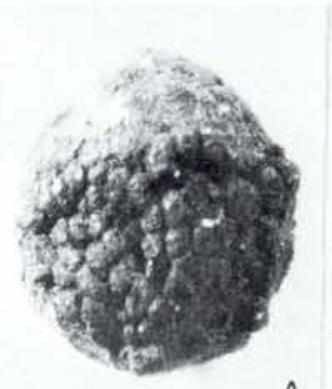

A

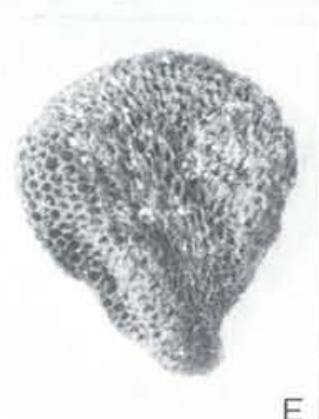

E

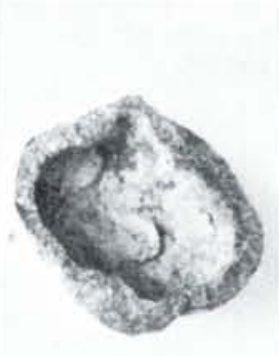

B

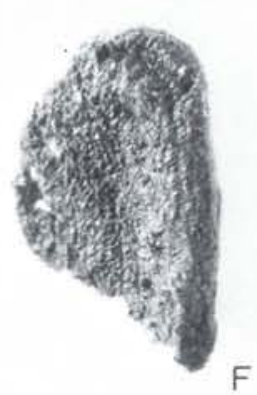

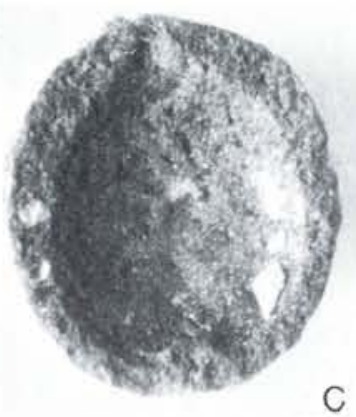

C
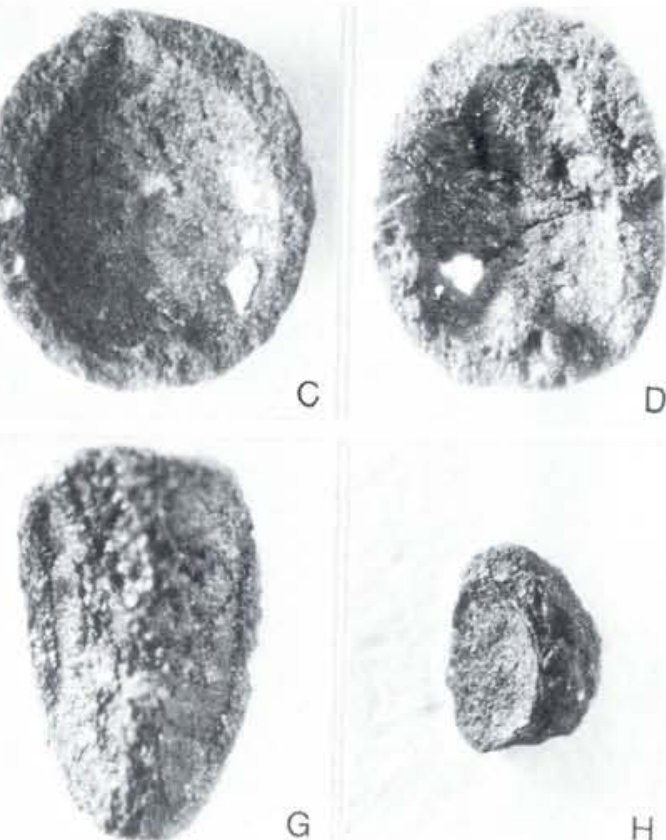

G

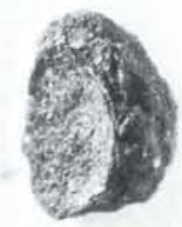

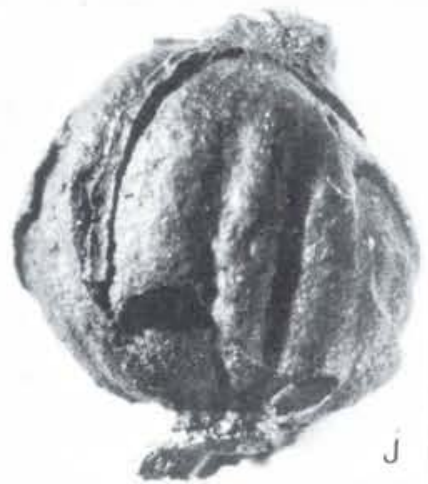

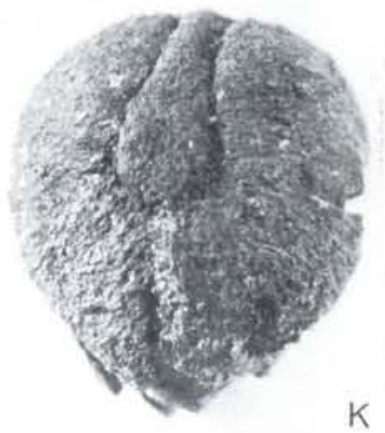

Fig. 8. A, Myrica cf. ceriferiformis endocarp with parts of exocarp preserved, $\times 15 . B$. Myrica $c f$. minima, endocarp. $\times 15$. $C-D$, Myrica $c f$. suppanii, endocarps, $\times 15$. E, Eurya stigmosa, seed, $\times 15 . F$, Visnea sp., seed, $\times 10 . G$, Arctostaphyloides

Plant remains assigned to Myrica are rather common in the Tertiary deposits of Denmark. From the lignitic clay at Silkeborg Vesterskov Mathiesen (1975) described a new species $M$. cimbrica based on the leaf remains. From Sønderskov and Salten Hartz (1909) described the endocarps of Carpolithes johnstrupii, which probably includes more species of Myrica. A few endocarps of Myrica were also found in the plantbearing clay at the Søby flora locality. In the Fasterholt flora endocarps of Myrica are very common (Friis 1975) and four species have been re- menzelii, part of fruit, $\times 15 . H$, Empetrum $s p$., endocarp, $\times 15$. I. Rhus cf. toxicodendron, fruit, $\times 10, \mathrm{~J}$, Vitis $c f$. silvestris, seed, $\times 10$.

cognised: $M$. cf. ceriferiformis, $M$. cf. minima, $M$. cf. suppanii and $M$. wiesaensis; a more detailed description and discussion of the Myrica endocarps will be given in the taxonomic treatment of the Fasterholt flora.

Family: Juglandaceae

Genus: Pterocarya Kunth

Pterocarya $\mathrm{sp}$.

Material: One valve of endocarp.

Occurrence: Dam 1. 
Remarks. Endocarps of Pterocarya are very common in the Fasterholt flora (Koch et al. 1973); they differ from the present specimens by having distinct longitudinal ridges on the surface of the endocarp. The lack of ridges on the Damgaard specimen might be due to the preservation. The endocarps of Pterocarya are closely related to those of Cyclocarya Iljinskaja and Sphaerocarya Dorofeev (Dorofeev 1970, Gregor 1975). The endocarp from Damgaard seems to be most related to Pterocarya limburgensis C. et E. M. Reid (1915), but due to the bad preservation the exact determination is not possible.

Family: Theaceae

Genus: Eurya Thunberg

\section{Eurya stigmosa (Ludwig) Mai}

Fig. 8E.

1860. Potamogeton stigmosus Ludwig - Ludwig p. 60, pl. 8: 13.

1960. Eurya stigmosa (Ludw.) nov.comb. - Mai p. 79, pl. 4: 8-17.

Material: 2 seeds

Occurrence: Dam 1, Dam 2.

Description. Seeds campylotropous, irregular ovoid. Dimensions of the two seeds: $2.0 \times 1.9$ $\mathrm{mm}$ and $0.9 \times 0.9 \mathrm{~mm}$. At dehiscence the seeds split into two equal valves. Seed wall about 0.15 $\mathrm{mm}$ thick. Seed-cavity curved, the limbs being of unequal length, separated by a condyle. Surface of seed-cavity smooth. The external surface is ornamented with conspicuous honey-comb shaped cells arranged in concentric rows parallel to the margin. The cells that overlie the condyle are elongated.

Remarks: Eurya stigmosa is widely distributed in the Tertiary floras of Europe (Mai 1960, 1971). The species was also found in the Fasterholt flora, but the seeds are all much smaller than the big specimen from Damgaard. Eurya stigmosa was compared to the extant $E$. japonica that occurs in temperate and subtropical regions of southeastern Asia. The species occurs in mountains in the tropical regions of Asia (Mai 1960, 1971).

\section{Genus: Visnea Linné}

Visnea sp.

Fig. 8F.
Material: 4 seeds.

Occurrence: Dam 1.

Description. Length of seed $2.5-3.6 \mathrm{~mm}$; breadth 2.2-2.5 mm. Seeds campylotropous, ovoid. Seed wall thick and consisting of two layers. Seed-cavity curved, limbs of unequal length, separated by the condyle composed of large cells. External cells of testa radially elongated and rectangular, about $0.1 \times 0.05 \mathrm{~mm}$, arranged in concentric rows parallel to the margin.

Remarks. The seeds from the Damgaard flora are related to those of Campylospermum hordwellense described by Chandler $(1925,1961)$ from the Eocene flora of Hordle, England (V.20034-35, V.42169-72 studied at the British Museum N.H.). The fossils were compared by Chandler (1961) to extant species of Ternstroemia and Anneslea (Theaceae). In a later study Mai (1971) referred the fossil species to the genus Visnea (Theaceae). The seeds from Damgaard differ from the English material mainly by being less flattened, possibly due to a smaller number of seeds in the fruits of the Danish material. As only single seeds were found in the Damgaard flora, the exact number of seeds per fruit is not known. Visnea hordwellensis (Chandler) Mai has 5-8 seeds per fruit and $V$. germanica Menzel (1913) has 3-5 seeds per fruit (Mai 1971) and probably the Danish material is most closely related to the German species.

The genus Visnea includes only one extant species Visnea mocanera. It is an evergreen shrub or small tree that occurs in woods in the mountains of the Canaries and Madeira (Melchior 1925).

Family: Ericaceae

Genus: Arctostaphyloides Kirchheimer

Arctostaphyloides menzelii Kirchheimer Fig. 8G.

1936. Arctostaphyloides menzelii n.sp. - Kirchheimer p. 117, pl. 12: 13.

Material: 5 fruits and 16 fragments of fruits. Occurrence: Dam 1, Dam 3.

Description. Fruits elliptic and somewhat flattened, 2.6-4.2 mm long and 2.1-3.4 $\mathrm{mm}$ in diameter, built of about 5 segments. Fruit wall very 
thick and occupying most of the fruit obscuring the seed-cavity. The cells are »fleshy « parenchymatous and isodiametric or slightly elongated, about $0.1 \mathrm{~mm}$ in diameter. The axis is fibrous.

Remarks. The fruits from the Damgaard flora were compared to fruits of Arctostaphyloides menzelii in the collections of the Botanical Institute, PAN, Cracow, and they were in complete agreement with the smaller, possibly undeveloped fruits of this species. The fossils were compared to living species of Arctostaphylos (Kirchheimer 1936), but the generic position of the fossil fruit is still unclear.

\section{Genus: Epacridicarpum Chandler}

\section{Epacridicarpum sp.}

Material: 5 valves of fruits.

Occurrence: Dam 3.

Description. Only the valves of the fruit are represented. They are about $0.9 \mathrm{~mm}$ long and 0.6 $\mathrm{mm}$ broad. They come from a drupe with 5 endocarps. The fruit wall is composed of two principal layers. The outer layer is brownish and consists of small isodiametric cells; it is only preserved in two specimens. The inner layer, the endocarp, is black and consists of elongated sclereids. The surface of the locule is shining and composed of elongated cells that diverge from the placenta.

Remarks. The fossil genus Epacridicarpum was established by Chandler (1960) and includes fruits comparable to fruits of Epacridaceae, of which the closer relationship is unknown. Chandler (1960, 1963) described the fruits of Epacridicarpum as capsules. Fruits of Epacridicarpum are the most numerous fossil in the $\mathrm{Fa}$ sterholt flora and the studies of this material have shown that the fruits are drupes related to the extant Arctostraphylos, but they differ from this genus in being much smaller. Mai (1976) suggested a relationship to the Cyrillaceae, but this suggestion is still unproved and until now the generic relationship is uncertain. The Danish material is very similar to $E$. mudense Chandler (1960) and E. headonense Chandler (1960), but differs in the length and shape of the sclereids. The species will be described in detail in the taxonomic treatment of the Fasterholt flora.
Genus? Tribe Andromedeae?

Material: 1 framgent of fruit.

Occurrence: Dam 3.

Description. One fragment of a five-loculed capsule with loculicidal dehiscence. The fragment consists of two carpels united by the septum. It is $1.2 \mathrm{~mm}$ long and about $0.9 \mathrm{~mm}$ broad. The segment is slightly incurved at the apex. Fruit wall about $0.5 \mathrm{~mm}$ thick; the external surface wrinkled.

Remarks. The characters are those of the Ericaceae, probably the tribe Andromedeae, but the fruit-segment is too incompletely preserved to be referred to any living genus.

Family: Empetraceae

Genus: Empetrum Linné

Empetrum sp.

Fig. $8 \mathrm{H}$.

Material: 1 endocarp.

Occurrence: Dam 3.

Description. Endocarp subcircular in outline, laterally compressed. Ventral margin straight and slightly incurved near the base, showing the position of the placenta; dorsal margin curved. Lenght $1.4 \mathrm{~mm}$, breadth $1.0 \mathrm{~mm}$.

Remarks. The endocarp has been compared to those of the extant Empetrum nigrum and they show considerable agreement. Empetrum has a discontinous distribution in the temperate regions of the Northern hemisphere and in temperate South America (Good 1964).

Family: Styracaceae

Genus: Halesia Ellis

Halesia crassa (C. et E. M. Reid) Kirchheimer Figs 9A-D.

1915. Camptotheca crassa sp. nov. - C. and E. M. Reid p. 121, pl. 14: 1a, b, 3-4.

1943. Halesia crassa (C. et E. M. Reid) - Kirchheimer, 505-515 pp.

Material: 1 endocarp.

Occurrence: Dam 1. 

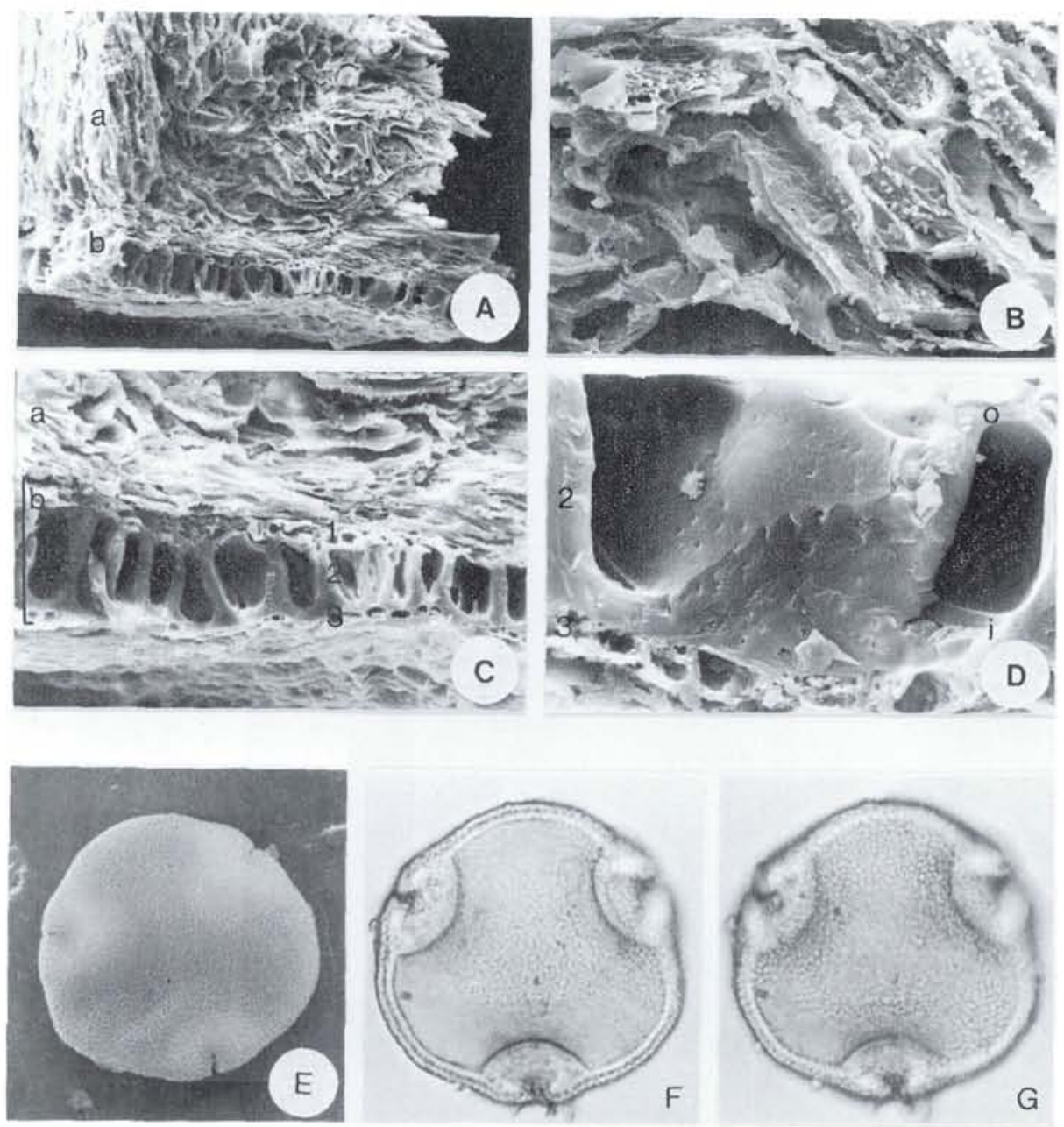

Fig. 9. A-D, Halesia crassa, SEM-micrographs of endocarp and seed wall. $A$, part of endocarp and seed wall, $\times 100 . B$, sclereids of inner endocarp wall, $\times 500 . C$, endocarp and seed wall, $\times$ 250. $D$, seed wall, $\times 1000 . a=$ endocarp wall, $b=$ seed wall, o $=$ outer periclinal wall, $I=$ inner periclinal wall, $I=$ outer layer

of seed wall, 2 = middle layer of seed wall, $3=$ inner layer of seed wall. $E-G$, Intratriporopollenites instructus, pollen grains. E, SEM-micrograph of pollen grain, $\times 1000 . F-G$, light microscope-micrograph of pollen grain, same grain, $F$, lower focus of $G \times 1000$.

Description. Endocarp fusiform, $16 \mathrm{~mm}$ long and $6 \mathrm{~mm}$ wide, flattened. Apex somewhat acuminating, style not preserved. Surface of endocarp much abraded with indistinct longitudinal ridges. Endocarp 2-loculed (?), one locule being fertile, the other sterile. The endocarp wall is very thick, brownish and composed of two distinct layers. The outer layer is $0,5 \mathrm{~mm}$ thick, consisting of slightly elongated sclereids, regularly arranged. The inner layer is composed of elongated, irregularly arranged sclereids, it pierces the outer layer in a few places. The seed wall is black, $0.045-0.060 \mathrm{~mm}$ thick and consists of three lay- ers (fig. 9C). The outer layer is $0.01-0.02 \mathrm{~mm}$ thick and built of parenchymatous cells in few rows, the cells are about $0.008 \mathrm{~mm}$ wide and $0.006 \mathrm{~mm}$ high, often compressed. The middle layer of the seed wall is uniseriate and composed of conspicuous columnar cells $0.035-0.045 \mathrm{~mm}$ high and $0.015-0.040 \mathrm{~mm}$ wide. The outer periclinal walls are about $0.002 \mathrm{~mm}$ thick and the inner about $0.008 \mathrm{~mm}$. The anticlinal walls are about $0.005 \mathrm{~mm}$ thick, slightly pitted (fig. 9D). The inner layer of the seed wall is parenchymatous, $0.006-0.015 \mathrm{~mm}$ thick, built of one or few layers of strongly pitted cells (fig. 9D). 
Remarks. The surface of the endocarp is much abraded and the identification of the fossil is based on the internal structure and size of the endocarp. It shows considerable agreement with the features of Halesia crassa from, the Upper Miocene flora of Kausche, Niederlausitz, as stated by Kirchheimer (1943). The species was first described by Reid \& Reid (1915) from the Pliocene flora of Swalmen, the Netherlands, as Camptotheca crassa. Later Kirchheimer (1943) assigned the species to Halesia, comparing it with extant Halesia carolina from eastern North America.

The genus Halesia includes four species of decidous shrubs or trees. Three species are found in North America and one in China. They occur on wet soil in rich woods, along river banks and at the edge of swamps. The fruits are two- or four-winged drupes (Correll \& Correll 1972).

Halesia is represented in only a few fossil floras of Europe ranging in age from Lower Miocene to Upper Pliocene (Mai 1965, Tralau 1965). In western Siberia Halesia crassa is recorded back in the Middle Oligocene (Novomichailovskaja) by Dorofeev (1963).

Halesia crassa is very common in the Søby flora, represented by endocarps and winged fruits. Investigation of the fruits show that they are four-winged (Christensen personal communication 1978). Winged fruits of Halesia from the Upper Pliocene of Weilerswist, Germany, were assigned to Halesia cf. carolina by Tralau (1965). He stated that the affinity of the winged fruits from Weilerswist with the endocarps of Halesia crassa is unclear. However, both the winged fruites of $H$. cf. carolina and the endocarps of $H$. crassa closely resemble $H$. carolina and they are clearly distinguished from $H$. monticola and $H$. diptera by their smaller size; $H$. diptera is also distinguished from $H$. carolina by having two-winged fruits (Kirchheimer 1943, Dorofeev 1963, Tralau 1965).

Endocarps from the Middle Miocene flora of Wackersdorf, Germany, described by Gregor (1975) as Halesia cf. crassa differ from the Danish specimen in their smaller size.

Family: Tiliaceae

Genus: Intratriporopollenites Pflug et Thomson
Intratriporopollenites instructus ( $\mathrm{R}$. Potonié) Thomson et Pflug

Figs $9 \mathrm{E}-\mathrm{G}$.

1931. Tiliae-pollenites instructus - R. Potonié p. 556, fig. 9.

1953. Intratriporopollenites instructus (R. Pot. \& Ven.) n. comb. - Thomson \& Pflug p. 89, pl. 10: 14-23.

Material: One group of anthers with numerous pollen grains.

Occurrence: Dam 3.

Description. Anthers closely spaced and embedded in a brownish tissue. The group of anthers is a fragment of a larger, possibly globular cluster. More than 30 elongated and slightly curved pollen sacs were counted at the fragment. Each sac contains numerous pollen grains. The pollen grains are tri-colporate, oblate in equatorial view and inter-semi-angular or slightly inter-hexagonal in polar view (figs $9 \mathrm{E}-\mathrm{F}$ ). Greatest diameter $31-40 \mu \mathrm{m}$, average $=35 \mu \mathrm{m}, 100$ specimens being measured. The polar axis is $17-20 \mu \mathrm{m}$, only few specimens were measured. The grains are heteropolar, tectate and intrareticulate. The endexine is strongly thickened around the apertures, the shape of the aperture area being lenticular, $11-15 \mu \mathrm{m}$ in diameter and 6-9 $\mu \mathrm{m}$ high.

Remarks. The pollen grains of Intratriporopollenites instructus from the Damgaard flora were studied by the use of light microscope as well as SEM and TEM, and a detailed description of the species is given in a separate paper by Friis \& Pedersen (in prep.).

Similar pollen grains were previously recorded from the Søby-Fasterholt area (Ingwersen 1954, Mai 1961).

The species ranges in age from the Upper Oligocene into the Lower Pliocene with culmination in the Middle Miocene (Mai 1961).

Family: Droseraceae

Genus: Aldrovanda Linné

Aldrovanda praevesiculosa Kirchheimer

1941a. Aldrovanda praevesiculosa n.sp. - Kirchheimer p. 309, fig. 1. 
Material: 1 fragment of seed.

Occurrence: Dam 5.

Remarks. A small fragment, $0.8 \times 0.5 \mathrm{~mm}$, was found with part of the neck preserved. The external surface and the wall structure of Aldrovanda are so characteristic that even very small fragments can be determined. The fragment from Damgaard agrees in every respect with seeds of Aldrovanda praevesiculosa from the Fasterholt flora. The genus Aldrovanda includes only one extant species $A$. vesiculosa. It is an aquatic plant that grows in shallow water. The geographical range is discontinuous within the subtropical and tropical regions of the world (Kirchheimer 1941a).

Family: Lythraceae

Genus: Decodon Gmelin

Decodon gibbosus (E. M. Reid) E. M. Reid

1920. Diclidocarya gibbosa n.sp. - E. M. Reid p. 83, pl. 4: 23, 25 .

1929. Decodon gibbosus - E. M. Reid in P. A. Nikitin, s. 37, pl. 589: 7-9.

Material: 2 seeds.

Occurrence: Dam 3.

Remarks. The seeds agree in shape and size with those of Decodon gibbosus. The preservation of the seeds is rather bad and they cannot be studied in detail. The species is very common in the Fasterholt flora. Decodon includes one extant species, $D$. verticillatus, that is restricted to eastern North America.

Family: Haloragaceae

Genus: Proserpinaca Linné

\section{Proserpinaca brevicarpa Dorofeev}

Fig. 8I

1976. Proserpinaca brevicarpa Dorof. sp.nov. Dorofeev p. 1037, fig. 1: 1-4.

Material: 2 fruits.

Occurrence: Dam 3.

Description. Fruits four-loculed, four-lobed nuts, nearly tetragonal and slightly narrowed near the apex. Length of fruits $1.7 \mathrm{~mm}$, breadth $1.0-1.3$ $\mathrm{mm}$. External surface with 8 thin longitudinal nerves (ribs), one that overlies each septum and one slightly winged, on the edges of the fruit, the latter has small thornlike projections. Between the longitudinal ribs smaller anastomosing ribs form a coarse reticulum. Apically thornlike remains of the calyx-veins have been preserved.

Remarks. Four fossil species of Proserpinaca have been described from the Tertiary and Quarternary of Europe and Asia. The Endocarps of $P$. brevicarpa Dorofeev (1976), P. europaea Dorofeev (1976) and $P$. pterocarpa (Dorofeev 1958) were compared to the extant $P$. palustris; they differ from the endocarps of $P$. reticulata $C$. et E. M. Reid (1915), comparable to the extant $P$. pectinata, by having more sharply angled ribs on the surface and by having more or less pronounced wingliked projections on the edges of the fruits. Dorofeev (1976) emphasized that the Oligocene specimens of Proserpinaca have a wide wing, the Miocene fruits have a narrow wing and the Pliocene fruits are wingless. The Danish specimens are slightly winged and they are in agreement with the narrowly winged Miocene species $P$. brevicarpa, described from the Upper Miocene of Byelorussia by Dorofeev (1976). Two fruits of Proserpinaca from the plantbearing clay at the Søby flora locality are similar to the fruits from the Damgaard flora. The Byelorussian specimens of $P$. brevicarpa are all three-loculed, whereas the Danish fruits are four-loculed. However, four-loculed fruits of Proserpinaca have been found in fossil floras of Poland (Szafer 1954, Raniecka-Bobrowska 1959), Czechoslovakia (Bůžek \& Holý 1964) and Western Siberia (Nikitin 1965). In Europe four-loculed fruits were recorded back in the Lower Miocene (Büžek \& Holý 1964), whereas three-loculed fruits were recorded back in the Upper Miocene, where they were found together with four-loculed specimens (Raniecka-Bobrowska 1959); in the Pleistocene flora of Mizerna III four-loculed fruits were also found together with three-loculed specimens (Szafer 1954). Table 5 shows the stratigraphic range and locule number of fossil Proserpinaca-fruits in Europe. The fruits of extant Proserpinaca are all three-loculed, and it is possible that a reduction from four to three locules have occurred in the Upper Miocene. This was also suggested by Bůžek \& Holý (1964).

Proserpinaca includes two extant species of 
Table 5. Number of locules in fossil Proserpinaca-fruits in Europe.

\begin{tabular}{|c|c|c|c|c|}
\hline Age & $\begin{array}{l}\text { Number of } \\
\text { locules }\end{array}$ & Locality & Author & \\
\hline Pleistocene & $\begin{array}{r}3 \\
43 \\
3\end{array}$ & $\begin{array}{l}\text { Mizerna III/IV } \\
\text { Mizerna III } \\
\text { Mizerna II/III }\end{array}$ & Szafer 1954 & \\
\hline U. Pliocene & 3 & Mizerna II & Szafer 1954 & \\
\hline M. Pliocene & $\begin{array}{l}3 \\
3\end{array}$ & $\begin{array}{l}\text { Mizerna I-I/II } \\
\text { Baldero, Razlog }\end{array}$ & $\begin{array}{l}\text { Szafer } 1954 \\
\text { Palamarev } 1970\end{array}$ & \\
\hline L. Pliocene & $\begin{array}{l}3 \\
3\end{array}$ & $\begin{array}{l}\text { Reuver, Swalmen, Brusum } \\
\text { Krosćienko, Huba }\end{array}$ & $\begin{array}{l}\text { C. \& E. M. Reid } 1915 \\
\text { Szafer } 1954\end{array}$ & \\
\hline U. Miocene & $4 \begin{array}{r}3 \\
3\end{array}$ & $\begin{array}{l}\text { Brestkoj Region } \\
\text { Konin }\end{array}$ & $\begin{array}{l}\text { Dorofeev } 1976 \\
\text { Raniecka-Bobrowska } 1959\end{array}$ & \\
\hline M. Miocene & 4 & Søby-Fasterholt area & Present work & \\
\hline L. Miocene & 4 & $\begin{array}{l}\text { Chomutov-Most-Templice } \\
\text { Basin }\end{array}$ & Bủžek \& Holy 1964 & \\
\hline Recent & 3 & SE North America & Muencher 1944 & \\
\hline
\end{tabular}

aquatic plants, restricted to east and southeast North America (Muencher 1944).

Family: Anacardiaceae

Genus: Rhus

\section{Rhus cf. toxicodendron}

Fig. 8J.

Material: 1 fruit.

Occurrence: Dam 3.

Description. Fruit oval, slightly oblique and laterally flattened, bisymmetric and somewhat pointed at the apex. At the base there are remains of a coriaceous calyx. The fruit has about 12 longitudinal ridges running from apex to base. Length $4.8 \mathrm{~mm}$, breadth (dorsiventrally) $4.0 \mathrm{~mm}$, breadth (laterally) $2.5 \mathrm{~mm}$. In some places the surface seems to be covered by a thin layer of inorganic material, or possibly resin.

Remarks. The fruit has been compared to several species of the Anacardiaceae and there is considerable agreement with the fruits of Rhus toxicodendron, but this differs from the fossil fruit by having more irregular longitudinal ridges. Rhus toxicodendron is restricted to the Atlantic North America Region (Good 1964).

Family: Rhamnaceae

Genus: Paliurus Miller

\section{Paliurus sp.}

Material: 1 fruit and 1 fragment of fruit with seed. Occurrence: Dam 3.

Remarks. The preservation of the fruit does not allow any detailed description, and the material has not been referred to any species. Fruits of Paliurus are very common in the Fasterholt flora, and seeds of Paliurus similar to the seed from Damgaard were also found in the Fasterholt flora together with the small plant remains; they are thought to be immature because of their small size and wrinkled surface.

Paliurus includes eight extant species of shrubs and small trees that occur in the warm temperate and subtropical regions of Europe and Asia (Wettstein 1935).

Family: Vitaceae

Genus: Vitis Linné

Vitis cf. silvestris Gmelin

Fig. $8 \mathrm{~K}$.

Material: 1 seed and 3 fragments of seeds. Occurrence: Dam 3, Dam 4.

Description. Seeds ovate, at the base narrowed to a short beak. Chalaza elongated or spathulate. There are no dorsal radiate markings. Ventral infolds about $2 \mathrm{~mm}$ long and up to $0.4 \mathrm{~mm}$ wide, parallel with smooth external margins. Raphe ridge not raised above main body of seed. The raphe is not fully preserved, but seems to be thread-like. Length $4.1 \mathrm{~mm}$ breadth $3.6 \mathrm{~mm}$. 
Remarks. The terms used in the description of the seeds are those used by Tiffney \& Barghoorn (1976). The seeds are closely related to those of Vitis cf. silvestris figured by Kirchheimer (1938b) from Reuver and Hoogerheide, the Netherlands, and from Klettwitz, Germany. They are also related to the fossil species $V$. teutonica. As only few and badly preserved specimens were found, the material has not been referred to a fossil species. Seeds of Vitis are very common in the Fasterholt flora, where the genus is represented by more species.

Class: Monocotyledones

Family: Alismataceae

Genus: ?

Figs 10A-E.

Material: 7 seeds.

Occurrence: Dam 3, Dam 5.

Description. Seeds amphitropous, elongated, horseshoe-shaped and laterally flattened, 1.0-1.4 $\mathrm{mm}$ long and $0.6-0.7 \mathrm{~mm}$ wide. Longitudinal axis somewhat curved. Limbs of nearly equal length, the micropylar limb being about $0.5 \mathrm{~mm}$ longer than the chalazal limb, and also a little wider. Seeds yellow. or brownish with a smooth and shining surface; the cell structure is inconspicuous.

Remarks. The seed characters are those of the Alismataceae. The material has been compared to seeds of Alisma, Caldesia, Echinodorus and Sagitaria. The fossils are most related to the seeds of Alisma plantago-aquatica, but the seeds of Caldesia are also similar; as the fruits were not found it is not possible to refer the fossil seeds to any genus, but only to the family Alismataceae. Similar seeds were described by Dorofeev (1963) from the Tertiary of western Siberia as Alismataceae gen. 3 and by Negru (1972) from the Miocene flora of Moldavia as Alisma sp. Similar seeds were also found in the Fasterholt flora. Few fruits of Caldesia were likewise found in the Fasterholt flora.

Family: Potamogetonaceae

Genus: Potamogeton Linné

\section{Potamogeton heinkei Mai}

Figs 10F-G.

1960. Potamogeton heinkei sp. nov. - Mai p. 78, pl. 4: 1-6, fig. 3

\section{Material: 2 endocarps.}

Occurrence: Dam 4.

Description. Endocarps obovate and laterally flattened. Neither stalk nor style are preserved, and both apex and base are rounded. Dimensions of the two endocarps: $1.5 \times 1.0 \mathrm{~mm}$ and $1.7 \times$ $1.1 \mathrm{~mm}$. Ventral area slightly convex, sides flat with a central depression, about $0.3 \mathrm{~mm}$ long and $0.15 \mathrm{~mm}$ wide; tissue of the central depression usually abraded. Dorsal area rounded, the germination valve is broken in both specimens, but a small fragment remains at the base showing a flattened roof-shaped profile. Valve not reaching base of style, but stops about $0.5 \mathrm{~mm}$ from the top. Lateral surface shows long, narrow cells, elongated parallel to the curve of the locule; an
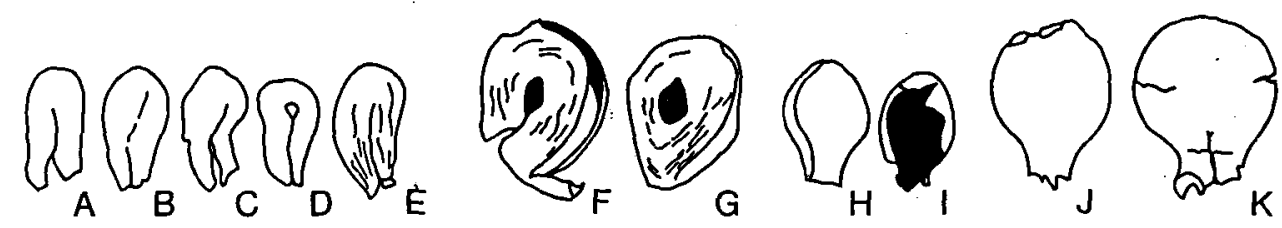
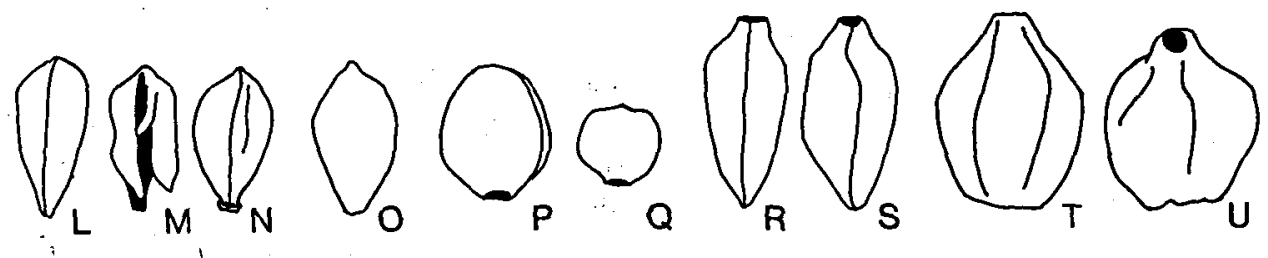

Fig. 10. A-E, Alismataceae, seeds. F-G, Potamogeton heinkei, endocarps. $H-I$, Cladium reidiorum, endocarps. $I-K$, Cladium cf. crassum, endocarps. $L-N$, Scirpus ragozinit, fruits. $O$, Scirpus (?) sp., fruit. P, Cyperaceae Genus? sp. 1, endocarp. $Q$,
Cyperaceae Genus? sp. 2, endocarp. $R-U$, Sparganium camenzianum, endocarps, $R$ and $S$ same specimen, $T$ and $U$ same specimen. $\times 10$. 
outer layer of small cells is sometimes preserved. Endocarp wall about $0.1 \mathrm{~mm}$ thick. Seed-cavity curved and has a shining surface showing long narrow cells aligned parallel to the curvature.

Remarks. The terms used in the description of the endocarps are mainly those used by Aalto (1970). The characters of the endocarps agree with those of the subsection Colorati (Graebn.) Hagstr. The fossils are closely related to Potamogeton heinkei described from the Lower Miocene (?) flora of Hartau, GDR (Mai 1960). They differ from the related $P$. wiesaensis by having a rounded valve without keel. Endocarps of Potamogeton were also found in the Fasterholt flora, two of these specimens are very close to the fruits from Damgaard; nine specimens differ by being smaller and by having a distinct keeled valve.

The genus Potomageton has a cosmopolitan distribution; it includes about 100 species of aquatic plants (Good 1964).

Family: Cyperaceae

Genus: Scirpus Linné

\section{Scirpus ragozinii Dorofeev}

Figs 10L-N.

1963. Scirpus ragozinii Dorofeev sp.nov. - Dorofeev p. 123, pl. 13: 38-45, fig. 18: 1-6.

Material: 12 fruits and 8 fragments of fruits. Occurrence: Dam 2, Dam 3, Dam 5.

Description. Fruits obovate, three-sided, apex narrowed to a short style-base, about $0.7 \mathrm{~mm}$ long and $1.2 \mathrm{~mm}$ wide. At the base the fruit has the remains of the bristles. Length of fruit: $1.4-1.6 \mathrm{~mm}$, breadth: $0.6-0.8 \mathrm{~mm}$. Surface black and shows longitudinally aligned, elongated cells; the cell walls also make a slightly transverse pattern. Fruit wall about $0.2 \mathrm{~mm}$ thick.

Remarks. The fruits are closely related to those of Scirpus ragozinii described by Dorofeev (1963) from Oligocene deposits of western Siberia. It was compared to the extant $S$. mucronatus, $S$. supinus and $S$. melanospermus (Dorofeev 1963). Fruits ascribed to $S$. ragozinii are very common in the Fasterholt flora.

Scirpus (?) sp.

Fig. 100.
Material: 1 fruit.

Occurrence: Dam 3.

Description. Fruit obovate, two-sided with a short pointed stylebase. Surface dark-brownish and shows very narrow cells, longitudinally aligned; there is no transverse pattern. Length of fruit: $1.5 \mathrm{~mm}$, breadth: $0.8 \mathrm{~mm}$.

Remarks. As only one specimen of rather bad preservation was found the generic position of the fossil is unclear, but it is related to fruits of extant Scirpus.

\section{Genus: Cladium Beauvois}

\section{Cladium reidiorum Nikitin}

Figs $10 \mathrm{H}-\mathrm{I}$.

1948. Cladium reidiorum (m.m.) (Nomen nudum) - P. A. Nikitin p. 1103.

1965. Cladium reidiorum Nikitin sp.nov. - P. A. Nikitin p. 62, pl. 6: 10-16, 19.

Material: 1 endocarp and one fragment of endocarp.

Occurrence: Dam 4.

Description. Endocarp obovate, rounded in longisection and slightly triangular in transection, $1.2 \mathrm{~mm}$ long and $0.8 \mathrm{~mm}$ broad. Fruit contracted at the base to a short neck, $0.2 \mathrm{~mm}$ long and 0.3 $\mathrm{mm}$ wide. At the edges of the neck there are remnants of the basal extension. Apex rounded with a very short mucronate style-base. Three inconspicuous longitudinal ridges extend from the apex. Endocarp wall about $0.05 \mathrm{~mm}$ thick.

Remarks. The endocarps from Damgaard are clearly assignable to Cladium reidiorum described from the Tertiary of western Siberia by Nikitin (1965). The species was also recorded in the Fasterholt flora.

\section{Cladium cf. crassum Negru}

Figs 10J-K.

Material: 2 endocarps.

Occurrence: Dam 2, Dam 4.

Description. Dimensions of the two endocarps: $1.8 \times 1.4 \mathrm{~mm}$ and $1.4 \times 1.2 \mathrm{~mm}$. Basal neck about $0.4 \mathrm{~mm}$ long and $0.6 \mathrm{~mm}$ wide. 
Remarks. The endocarps from Damgaard are related to Cladium crassum described by Negru (1972) from the Miocene of Moldavia, USSR, but they differ from the Moldavian material by being a little smaller. They differ from $C$. reidiorum by their larger size and broader neck.

Genus ? sp. 1.

Fig. 10P.

Material: 2 endocarps.

Occurrence: Dam 3.

Description. Endocarp 1.3-1.4 mm long and 1.2 $\mathrm{mm}$ broad, subglobular, two-sided, narrowed at the base to an inconspicuous short neck with a circular aperture, about $0.2 \mathrm{~mm}$ in diameter; apex slightly pointed. From apex two longitudinal furrows extend to the base, one at each side. Surface smooth, somewhat abraded with small equiaxial cells.

Remarks. The endocarps are related to the Cyperaceae, but the generic position is unclear, They are comparable with other fossil endocarps assigned to the Cyperaceae, e.g. Caricoidea obscura Chandler (1960), but as the exocarp has not been preserved the identification of the endocarp is not possible. Endocarps similar to the above were also found in the Fasterholt flora.

Genus? sp. 2.

Fig. 10Q.

Material: 1 endocarp.

Occurrence: Dam 3.

Description. Endocarp $0.8 \mathrm{~mm}$ long and $0.9 \mathrm{~mm}$ broad, two-sided and subglobular, at the base narrowed to a short neck.

Remarks. The endocarp is rather badly preserved; it is similar to endocarps ascribed to Cyperaceae from the Fasterholt flora, which are comparable with species of the fossil genus Caricoidea Chandler (1957). It differs from the other endocarps (Genus ? sp. 1) by it's smaller size and a more distinct neck. The better preserved specimens from the Fasterholt flora also have indistinct longitudinal ridges.

Family: Sparganiaceae

Genus: Sparganium Linné
Sparganium camenzianum Kirchheimer

Figs 10R-U.

1941b. Sparganium camenzianum sp. nov. Kirchheimer p. 225, fig. 18.

Material: 2 endocarps.

Occurrence: Dam 2, Dam 3.

Description. - Endocarps fusiform, one-loculed, irregular angled in cross-section, at the apex narrowed to a short neck with a subcircular aperture, about $0.2 \mathrm{~mm}$ in diameter. Outer surface somewhat abraded showing very small cells. One specimen has six longitudinal bundles running from base to apex; on the other specimens the bundles are obscure. Dimensions of the two endocarps: $2.0 \times 1.0 \mathrm{~mm}$ and $2.1 \times 1.5 \mathrm{~mm}$.

Remarks. The endocarps from Damgaard were compared to material of Sparganium camenzianum from Wiesa, determined by Dr. Mai, Berlin, and they agree in both size and shape. $\mathrm{Nu}$ merous endocarps ascribed to $S$. camenzianum were also recorded from the Fasterholt flora. They are usually narrow and 3-angled and generally smaller than the specimens from Damgaard.

Incertae Sedis

Genus: Carpolithus Linné

Carpolithus sp. 1.

Figs $11 \mathrm{~A}-\mathrm{B}$.

Material: 1 fruit.

Occurrence: Dam 4.

Description. Fruit ovoid, three-sided and three-loculed, $1.5 \mathrm{~mm}$ long and $1.2 \mathrm{~mm}$ broad. Placenta basal, projecting and globular, about 0.2 $\mathrm{mm}$ in diameter. Surface of locule dull with slightly elongated cells, about $0.006 \mathrm{~mm}$ long, diverging from the placenta. Fruit wall $0.06 \mathrm{~mm}$ thick with inconspicuous cell-structure. Central axis $1.5 \mathrm{~mm}$ thick.

Remarks. The fruit has been compared to three-loculed fruits from several families (e.g. Droceraceae, Ericaceae, Euphorbiaceae, Theaceae, Violaceae), but the systematic position is still unknown.

Carpolithus sp. 2.

Fig. 11F. 


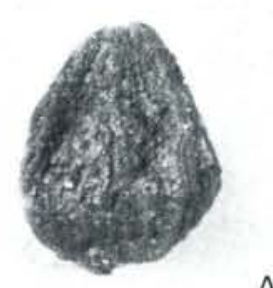

A
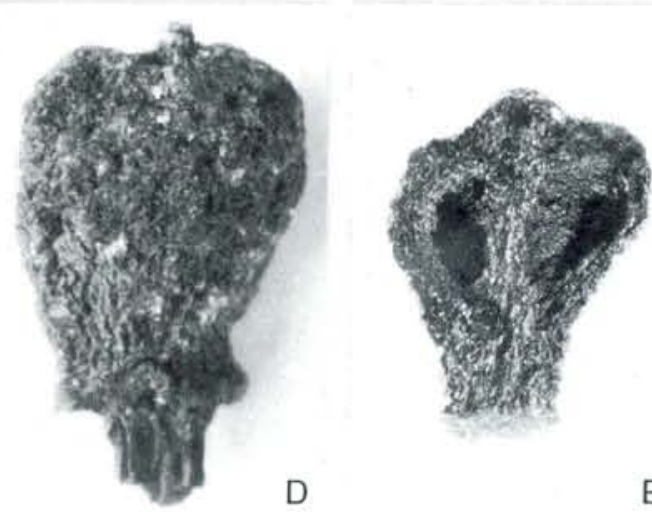

$E$

Fig. 11. $A-B$, Carpolithus sp. 1. A, external view of fruit. $B$, internal view of same specimen. $C$, Carpolithus sp. 3, fruit. $D-E$,

Material: 1 fruit.

Occurrence: Dam 3.

Description. Fruit woody, three-sided and one-loculed, $2.2 \mathrm{~mm}$ long and $1.3 \mathrm{~mm}$ broad. Fruit wall $0.1 \mathrm{~mm}$ thick, consisting of small inconspicuous cells; outer epidermal layer black. Surface of fruit with irregular longitudinal ridges. No seeds were observed.

Remarks. The systematic relationship of the fruit is unknown.

\section{Carpolithus sp. 3.}

Fig. 11C.

Material: 1 fruit.

Occurrence: Dam 1.

Description. Fruit flattened, ovoid, $1.5 \mathrm{~mm}$ long and $1.2 \mathrm{~mm}$ wide. Surface almost smooth with small, nearly equaxial cells.

Remarks. The systematic position of the fruit is unknown.

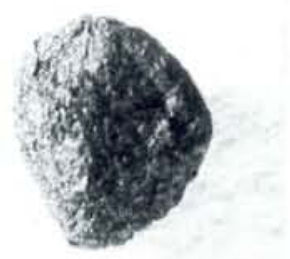

C

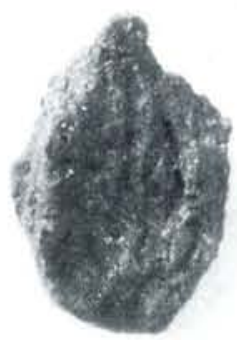

F

Carpolithus sp. 4. D, fruit with stalk. E, internal view of same specimen. $F$, Carpolithus $s p 2$, fruit. $\times 15$.

Carpolithus sp. 4.

Figs 11D-E.

\section{Material: 1 fruit.}

Occurrence: Dam 3.

Description. Fruit elongated obovoid, with a short stalk and remnants of a coriaceous calyx at the base. Apically remains of a short, apparently five-lobed style can be seen. Length of fruit with stalk: $3.2 \mathrm{~mm}$, length without stalk: $2.2 \mathrm{~mm}$; breadth: $1.7 \mathrm{~mm}$. Fruit five-loculed, the locules being about $0.8 \mathrm{~mm}$ long and situated in the apical part of the fruit (fig. 11E). Placentation subapical; seeds have not been observed. Central axis about $0.2 \mathrm{~mm}$ broad. Fruit wall about 0.2 $\mathrm{mm}$ thick at the apical part, the cell-structure indistinct, but the cells appears to be »fleshy«. Bundles to the placentae and fruit wall diverge from the stalk. Surface wrinkled; epidermal cells very small, isodiametric. The ovary is superior and the fruit apparently a berry.

Remarks. The characters agree with those of the Ericaceae, possibly tribe Arbuteae, but it has not 
been possible to refer it with certainty to this family.

Acknowledgements. The author wishes to thank K. Raunsgaard Pedersen and $\mathrm{H}$. Friis for helpful discussion and encouragement during this work. I am grateful to L. Eklund, S. R. Jacobsen, B. Larsen, J. Gissel Nielsen and J. Sommer for their valuable help in preparation of the manuscript and figures. I am also greatly indebted to $\mathrm{M}$. Collinson, who gave valuable criticism of the paper and improved the English text. C. Shute and G. F. Elliot, British Museum (Natural History), and M. Lańcucka-Srodoniowa, Cracow, are thanked for their help during my visit to their institutions. The study has been supported by the Danish Natural Science Research Council as part of the Søby-Fasterholt project.

\section{Dansk sammendrag}

En ny fossil flora, Damgaard floraen, beskrives fra den forladte brunkulsgrav »Damgaard S i Søby-Fasterholt området. Floraen, som overvejende består af frugter og frø, er udslemmet fra lyst skrålejret sand tilhørende den mellem miocæne Odderup formation; sandet overlejres af den marine Hodde Formation, som er henregnet til den øverste del af Mellem Miocan. Prøver af det lyse sand blev indsamlet langs gravens østvæg. Fem af disse prover indeholdt fossile frugter, frø, kviste og pollensakke, som samlet beskrives som Damgaard floraen. Floraen, som omfatter 36 arter, er karakteriseret ved en rig forekomst af endokarpier af Comptonia srodoniowae sp. nov. Frugter og frø af Taxodium, Brasenia, Myrica, Arctostaphyloides og Scirpus er ligeledes almindelige i floraen, mens de øvrige arter kun er repræsenteret ved fă eksemplarer.

Floristisk-klimatiske undersøgelser viser, at Damgaard floraen er en arktotertiær flora, som har vokset under varmt tempererede til subtropiske forhold. Floraen har mange fælles træk med de to andre mellem miocæene floraer beskrevet fra Søby-Fasterholt området, Søby floraen og Fasterholt floraen. Forskellene mellem de tre floraer må først og fremmest søges $i$ deres forskellige bevaringsform; Søby floraen er en bladflora fundet $i$ et lersediment, mens Damgaard og Fasterholt floraerne hovedsageligt består af frugter og frø aflejret $i$ sand. Mens Damgaard floraen er ret artsfattig med planterester, som vidner om kraftig transportpåvirkning, er Fasterholt floraen meget rig, og fossileme synes kun at have været udsat for ringe transport.

\section{References}

Aalto, M. 1970. Potamogetonaceae fruits. I. Recent and subfossil endocarps of the Fennoscandian species. Acta Botanica Fennica, 88, 1-85.

Asgaard, U. \& Bromley, R. G. 1974. Sporfossiler fra den Mellemmiocæene transgression i Søby-Fasterholt omrădet. Dansk geol. Foren., Arsskrift for 1973, 11-19.

Bailey, I. W. \& Sinnott, E. W. 1916. The climatic distribution of certain types of angiosperm leaves. Am. journ. Bot. 3, 24-39.

Budancev, L. Ju. \& Gladkova, A. N. 1963. Myricales. In Takhtajan, A. (editor) Osnovy Paleontologii. Golosemennye i pokrytosemennye 486-488. Moscow: Gosteoltechizdat. (In Russian).

Bůžek, C. \& Holý, F. 1964. Small-sized plant remains from the coal formation of the Chomutov-Most-Teplice Basin.
Sbornik Geologickych Ved Paleontologie rada P, sv. 4, 105-134.

Chandler, M. E. J. 1925. The Upper Eocene flora of Hordle, Hants. Part I. Palcoontographical Society, 1923, 1-32.

Chandler, M. E. J. 1957. The Oligocene flora of the Bovey Tracey Lake Basin (Devonshire). Bull. Brit. Mus. (Nat. Hist.), Geol 3(3), 7-123.

Chandler, M. E. J. 1960. Plant remains of Hengistbury and Barton Beds. Bull. Brit. Mus (Nat. Hist.), 4(6), 193-238.

Chandler, M. E. J 1961. Flora of the Lower Headon Beds of Hampshire and the Isle of Wright. Bull. Brit. Mus. (Nat. Hist.), Geol, 5(5), 12-157.

Chandler, M. E. J. 1963. Revision of the Oligocene flora of the Isle of Wright. Bull. Brit. Mus. (Nat. Hist.), Geol. 6(3), 323-383.

Chaney, R. W. 1967. Miocene forest of the Pacific Basin: Their ancestors and their descendants. Jubilee Publ. Commem, Prof. Sasa. 60th Birthday, 209-239.

Christensen, E. F. 1975. The Søby Flora: Fossil plants from the Middle Miocene delta deposits of the Søby-Fasterholt area, Central Jutland, Denmark. I. Danmark geol. Unders. 2rk. 103, 1-41.

Christensen, E. F. 1976. The Søby Flora: Fossil plants from the Middle Miocene delta deposits of the Seby-Fasterholt area, Central Jutland, Denmark. II. Danmarks geol. Unders. $2 \mathrm{rk}, 108,1-49$.

Correll, D. C. \& Correll, H. B. 1972. Aquatic and wetland plants of southwestern United States. 1777 pp. Environmental Protection Acency.

Dorofeev, P. I. 1958. O novom vide roda Proserpinaca L. dlja tretǐnoj flory SSSR. Bot. Žur. 43(9), 1337-1340. (In Russian).

Dorofeev, P. I. 1963. Tretičnye flory zapadnoj Sibiri. 345 pp. Moscow and Leningrad: Akad. Nauk SSSR. (In Russian).

Dorofeev, P. I. 1966. O plodach Comptonia iz Tretixnych otloženij SSSR. Dokl. Akad. Nauk SSSR, 167(4), 910-913. (In Russian).

Dorofeev. P. I. 1970. K' sistematike nekotorych iskopaemych Juglandaceae. Bot Žurn. 55(11), 1596-1604. (In Russian).

Dorofeev, P. I. 1976. K sistematike neogenovych Proserpinaca Belorusii. Dokl. Akad. Nauk SSSR, 20(11), 1036-1038. (In Russian).

Dorofeev, P. I. Iljinskaja, I., Imachanitzkaja, N., Kolesnikova, T., Kutuzkina, E., Shilkina, I., Snigirevskaja, N., Sveshnikova, I. \& Zhilin, S. 1974. Fossil flowering plants of the USSR, I. 188 pp. Leningrad: Izd. Nauk (In Russian).

Dorofeev, P. I. \& Negru, A. G. 1970. Pro plodi rodu Myrica L. z. Miocenovich vidkladiv Ukraini ta Moldavij. Ukrain. Bot. Žurn., 27(4), 502-507. (In Russian).

Friis, E. M. 1974. Taxonomy of the Tertiary fossil fruit Carpolithes oestrupii from the Pleistocene of Denmark. Bull. ge ol. Denmark, 23, 265-268.

Friis, E. M. 1975. Climatic implications of microcarpological analyses of the Miocene Fasterholt flora, Denmark. Bull. geol. Soc. Denmark, 24. 179-191.

Friis, E. M. 1977a. Leaf whorls of Cupressaceae from the Miocene Fasterholt flora, Denmark. Bull. geol. Soc. Denmark, 26, 103-113.

Friis, E. M. 1977b. EM-studies on Salviniaceae megaspores from the Middle Miocene Fasterholt flora, Denmark. Grana 16, 113-128.

Friis, E. M. \& Pedersen, K. Raunsgaard in prep. Fine structure of Intratriporopollenites instructus from the Middle Miocene of Denmark.

Gladkova, A. N. 1965. Iskopaemye Myricaceae zapadnoj Sibiri. In Samojlovic, S. R. (editor) Paleofitologiceskij Sbornik, 142-447. Moscow: Izd. Nedra. (In Russian).

Good, R. 1964. The geography of the flowering plants, $518 \mathrm{pp}$. London and Colchester: Longmans. 
Gregor, H. -J. 1975. Die mittelmiozäne Mastixioideen-Floren aus den Braunkohlen-Tagebau Oder II bei Wackersdorf (Oberpfalz). Inaugural-Dissertation, 249 pp. München.

Hartz, N. 1909. Bidrag til Danmarks tertiære og diluviale flora. Danm. geol. Unders.2rk, 20,1-271.

Heer, O. 1853. Uebersicht der Tertiärflora der Schweiz. Mitt. Naturf. Ges. 3, 88-153.

Ingwersen, P. 1954. Some microfossils from Danish Late-Tertiary lignites. Danm. geol. Unders. 2rk, 80, 31-64.

Kirchheimer, F. 1935. Reste von Wasserpflanzen aus der Braunkohle des Niederlausitzer Typus. Zentralblatt $f$. Min. ect. Jahrg. 1935, B, 1, 25-31.

Kirchheimer, F. 1936. Beiträge zur Kenntnis der Tertiärflora. Früchte und Samen aus dem deutschen Tertiär. Palaeontogr. $\mathbf{B}, 82,73-128$.

Kirchheimer, F. 1938a. Beiträge zur näheren Kenntnis der Mastixioideen-Fiora des deutschen Mittel-bis Oberoligozäns. Beihefte zum Bot. Centralbl. B, 58, 304-367.

Kirchheimer, F. 1938b. Beiträge zur näheren Kenntnis der Vitaceen-Samenformen tertiären Alters. Planta, 28, 582-598.

Kirchheimer, F. 1939. Tertiäre Dicotyledonenreste und ihr systematische Wert. Flora N.F. 33, 239-292.

Kirchheimer, F. 1941a. Über ein Vorkommen der Gattung $A l$ drovanda L. im Alttertiär Thüringens. Braunkohle, 40(24), 308-311.

Kirchheimer, F. 1941b. Ein neuer Beitrag zur Kenntnis der Braunkohlenflora in der Lausitz. Beitr. z. Biologie d. Pflanzen, 27, 221-226.

Kirchheimer, F. 1943. Über den Nachweis der Styracaceen-Gattung Halesia Ellis im Tertiär Mitteleuropas. Planta, 33, 505-515.

Koch, B. E. \& Friedrich, W. L. 1970. Geologisch-Paläobotanische Untersuchung der Miozänen Braunkohlen bei Fasterholt in Jütland, Dänemark. Bull. geol. Soc. Denmark, 20, 161-191.

Koch, B. E. \& Friedrich, W. L. 1971. Früchte und Samen von Spirematospermum aus der miozänen Fasterholt flora in Dänemark. Palaeontogr. B, 136, 1-46.

Koch, B. E., Friedrich, W. L., Christensen, E. F. \& Friis, E. M. 1973. Den miocæne brunkulsflora og dens geologiske miljø i Søby-Fasterholt området sydøst for Herning. Dansk geol. Foren., Arsskrift for 1972, 1-57.

Koch, H. 1931. Zur Gliederung der Gattung Brasenia auf Grund der Samenvariabilität. Senckenbergiana, 13, 214-228.

Kownas, S. 1955. Tertiay flora from Dobrzyn-on-the-Vistula. Acta Geologica Polonica, 5(4), 439-512.

Larsen, G. \& Friis, H. 1973. Sedimentologiske undersøgelser af det jyske ung-tertiær. Dansk geol. Foren., Arsskrift for $1972,119-128$.

Ludwig, R. 1860. Fossile Pflanzen aus der ältesten Abteilung der Rheinisch-Wetterauer Tertiär-Formationen. Palaeontogr. 8, 39-208.

Mai, D. H. 1960. Über neue Früchte und Samen aus dem deutschen Tertiär. Paläont. Z, 34, 73-90.

Mai, D. H. 1961. Über eine fossile Tiliaceen-Blüte und tilioiden Pollen aus dem deutschen Tertiär. Geologie, 10(32), 54-93.

Mai, D. H. 1965. Der Florenwechsel im jüngeren Tertiär Mitteleuropas. Feddes Repertorium, 70, 157-169.

Mai, D. H. 1967. Die Florenzonen, der Florenwechsel und die Vorstellung über den Klimaablauf im Jungtertiär der Deutschen Demokratischen Republik. Abh. zentr. geol. Inst. 10, 55-81.

Mai, D. H. 1971. Über fossile Lauraceae und Theaceae in Mitteleuropa. Feddes Repertorium, 82(5), 313-341.

Mai, D. H. 1976. Fossile Früchte und Samen aus dem Mitteleozän des Geiseltales. Abh. zentr. geol. Inst. 26, 93-149.
Mathiesen, F. J. 1970. Palaeobotanical Investigations into some Cormophytic Macrofossils from the Neogene Tertiary Lignites of Central Jutland. Part II. Gymnosperms. Biol. Skr. Dan. Vid. Selsk. 17(3), 1-69.

Mathiesen, F. J. 1975. Palaeobotanical Investigations into some Cormophytic Macrofossils from the Neogene Tertiary Lignites of Central Jutland. Part III. Angiosperms. Biol. Skr. Dan. Vid. Selsk. 20(9), 1-59.

Melchior, H. 1925. Theaceae. In Engler, A. \& Prantl, K. (editors) Die natürlichen Pflanzenfamilien, 21 (2nd ed.), 109-154.

Menzel, P. 1913. Beitrage zur Flora der Niederrheinischen Braunkohlenformation. $J b$. preuss. geol. Landesanst. 34(1), 1-98.

Muencher, W. C. 1944. Aquatic plants of the United States. 374 pp. Ithaca and London: Cornell University Press.

Negru, A. G. 1972. Rannesarmatskaja flora severovostoka Moldavii. 169 pp. Kišinev: Akad. Nauk Moldavskoj SSR.

Nikitin, P. A. 1929. The systematic position of the fossil genus Diclidocarya E. M. Reid (with a note by Mrs. E. M. Reid having especial reference to $D$. gibbosa E. M. Reid and $D$. Menzelii E. M. Reid). Journal of Botany, 67, 33-38.

Nikitin, P. A. 1948. Pliocenovye flory s reki Obi v Rajone Tomska. Dokl. Akad. Nauk SSSR, 61(6), 1103-1106. (In Russian).

Nikitin, P. A. 1965. Akvitanskaja semennaja flora Lagernogo Sada (Tomsk). 119 pp. Tomsk: Izd. Tomsk Univ. (In Russian).

Nikitin, V. P. 1976. (Seeds and fruits in paleoflora of the Mamontova Gora). In Saks, V. N. (editor) (The miocene of Mamontova Gora. Stratigraphy and paleoflora). 131-194. Moscow: Izd. Nauka. (In Russian).

Palamarev, E. 1970. Fossile Floren aus Drei Braunkohlenbecken in Südwestbulgarien. Bulg. Akad. Nauk, 20, 35-79.

Potonié, R. 1931. Zur Mikroskopie der Braunkohlen. Tertiäre Sporen- und Blütenstaubformen. (4. Mitteilung). Braunkohle, 27, 554-556.

Raniecka-Bobrowska, J. 1959. Tertiary seed-flora from Konin (Central Poland). Inst. Geol. Biul., 130, 159-252.

Rasmussen, L. Banke 1961. De miocæne Formationer i Danmark. Danm. geol. Unders. 4rk, 4, 1-45.

Reid, C. \& Reid, E. M. 1915. The Pliocene floras of the Dutch-Prussian border. Mededeel. Rijksopsp. Delfstoffen, Hagues, 6, 1-158.

Reid, E. M. 1920. Recherches sur quelques grainès pliocenes du Pont-De-Gail (Cantal). Bull. Soc. Géol. France, 4(20), 48-87.

Reid, E. M. \& Chandler, M. E. J. 1933. The London Clay flora. 561 pp. London: Brit. Mus. (Nat. Hist.).

Růffle, L. 1976. Myricaceae, Leguminosae, Icacinaceae, Sterculiaceae, Nymphaeceae, Monocotyledones, Coniferae. Abh. zentr. geol. Inst. 26, 337-438.

Small, J. K. 1972. Manual of the Southeastern Flora. 1554 pp. New York: Hafner Publishing Company.

Spjeldnzs, N. 1975. Palaeogeography and facies distribution in the Tertiary of Denmark and surrounding areas. Norges geol. Unders. 316, 289-311.

Sternberg, K. 1823. Versuch einer Geognostisch-Botanischen Darstellung der Flora der Vorwelt. 1(3). Regensburg.

Szafer, W. 1946. The Pliocene Flora of Krościenko in Poland. I. General Part. Rozpr. Wydz. matem.-przyr. B, 72(1), 1-162.

Szafer, W. 1954. Pliocene flora from the vicinity of Czorsztyn (West Carpathians) and its relationship to the Pleistocene. Inst. Geol. Prace, 10, 1-238.

Szafer, W. 1961. Miocene flora from Stare Gliwice in Upper Silesia. Inst. Geol. Prace. 33, 1-205.

Thomson, P. W. \& Pflug, H. 1953. Pollen und Sporen des Mitteleuropäischen Tertiärs. Palaeontogr. B, 94, 1-138. 
Tiffney, B. H. \& Barghoorn, E. S. 1976. Fruits and seeds of the Brandon lignite. I. Vitaceae. Rev. Palaeobot. Palynol. 22, 169-191.

Tralau, H. 1965. Halesia cf. carolina L. (Styracaceae) im oberen Pliozän von Weilerswist in Westdeutschland. Botaniska Notiser, 118, 171-176.

Unger, F. 1840. Über die pflanzen- und Insektenreste von Rodoboj in Kroatien. N. Jb. f. Min. Geol. Jg. 1840, 374-377.

Unger, F. 1847. Chloris protogaea. Beiträge zur Flora der Vorwelt. 150 pp. Leipzig.
Wettstein, R. 1935. Handbuch der Systematischen Botanik. 1152 pp. Leipzig and Vienna: Franz Deuticke.

Wolfe, J. A. \& Barghoorn, E. S. 1960. Generic change in Tertiary floras in relation to age. Am. journ. of Science, Bradley Vol. 258-A, 388-399.

Zhilin, S. G. 1974. (The Tertiary floras of the Plateau Ustjurt (Transcaspia)). 122 pp. Leningrad: Izd. Nauka (In Russian). 